\title{
43. PALEOMAGNETISM OF LEG 119-HOLES 737A, 738C, 742A, 745B, AND 746A ${ }^{1}$
}

\author{
Hideo Sakai² and Barbara Keating ${ }^{3}$
}

\begin{abstract}
ODP Leg 119 drilled on the Kerguelen Plateau in the southern Indian Ocean and in Prydz Bay, Antarctica. A geomagnetic polarity zonation for the late Miocene to the Quaternary has been determined from the sediments of the Kerguelen Plateau. Hole 745B on the south Kerguelen Plateau provided the excellent reversal sequence for the last 6 Ma including the Cobb Mountain event in the Matuyama Chron and the unidentified subchron in the Gilbert Chron.

Hole $738 \mathrm{C}$ drilled a complete Cretaceous/Tertiary boundary. The volume magnetic susceptibility measurement around the Cretaceous/Tertiary boundary shows high values at the iridium-concentrated region. This supports the results by Worm and Banerjee (1987) that the high susceptibility and iridium concentration coincide at about the Cretaceous/Tertiary boundary.

The limestone sequence at Hole $738 \mathrm{C}$ from the Turonian to Santonian stage shows a low paleolatitude $\left(54^{\circ} \mathrm{S}\right) \mathrm{com}$ pared to the present $\left(64^{\circ} \mathrm{S}\right)$. This paleolatitude is nearly same as the Tertiary paleolatitude estimated from paleomagnetic poles of Antarctica.

At Hole $742 \mathrm{C}$ in Prydz Bay, a glacial sequence was penetrated to a depth of $316 \mathrm{mbsf}$. The magnetic susceptibility of this sequence correlated well with changes of lithology. The magnetic inclinations of the sequence from the middle Eocene to the Oligocene indicated a dominant normal polarity zone containing several short reversals.
\end{abstract}

\section{INTRODUCTION}

Ocean Drilling Program (ODP) Leg 119 drilled at six sites on the Kerguelen Plateau and five sites on Prydz Bay near Antarctica (Fig. 1). We introduce here the paleomagnetic results from four holes (Holes 737A, 738C, 745B, and 746A) on the Kerguelen Plateau and Hole $742 \mathrm{~A}$ in Prydz Bay.

Hole $737 \mathrm{~A}\left(50.23^{\circ} \mathrm{S} / 3.03^{\circ} \mathrm{E}\right)$ on the northern flank of Kerguelen Plateau is situated about at the present-day Antarctic Convergence region. Holes $745 \mathrm{~B}\left(59.69^{\circ} \mathrm{S} / 86.85^{\circ} \mathrm{E}\right)$ and $746 \mathrm{~A}$ $\left(59.67^{\circ} \mathrm{S} / 86.87^{\circ} \mathrm{E}\right)$ are situated on the southeastern slope of the plateau. The sediments at the Holes 737A, 745B, and 746A produced a magnetostratigraphy from late Miocene to Quaternary. Hole $745 \mathrm{~B}$ was drilled to the age of polarity Chron C3A without any significant core gaps. A comparison of the magnetostratigraphy of this hole with the published polarity sequence is studied in detail.

At Hole $738 \mathrm{C}\left(62.71^{\circ} \mathrm{S} / 82.79^{\circ} \mathrm{E}\right)$ on the south Kerguelen Plateau, a complete Cretaceous/Tertiary boundary sequence without bioturbation was obtained. Magnetization of the sequence including Cretaceous/Tertiary boundary was measured by passthrough cryogenic magnetometer. The magnetic susceptibility was measured in the same sequence. They were used for the study of the magnetic properties at the Cretaceous/Tertiary boundary, for comparison to the results of Worm and Banerjee (1987). Houtz et al. (1977) suggested that the origin of the south Kerguelen Plateau is oceanic or an oceanic island. However, Coffin et al. (1986) suggest that the northern, central, and southern parts of the plateau have different origins. The limestones drilled at Hole $738 \mathrm{C}$ range in age from Santonian to $\mathrm{Tu}$ ronian. The magnetization of these rocks was stable, and, therefore, was utilized to examine the tectonic history of southern Kerguelen Plateau.

\footnotetext{
${ }^{1}$ Barron, J., Larsen, B., et al., 1991. Proc. ODP, Sci. Results, 119: College Station, TX (Ocean Drilling Program).

2 Department of Earth Sclences, Toyama University, Gofuku 3190, Toyama 930, Japan.

${ }^{3}$ Hawaii Institute of Geophysics, University of Hawaii, 2525 Correa Road, Honolulu, HI 96822, U.S.A.
}

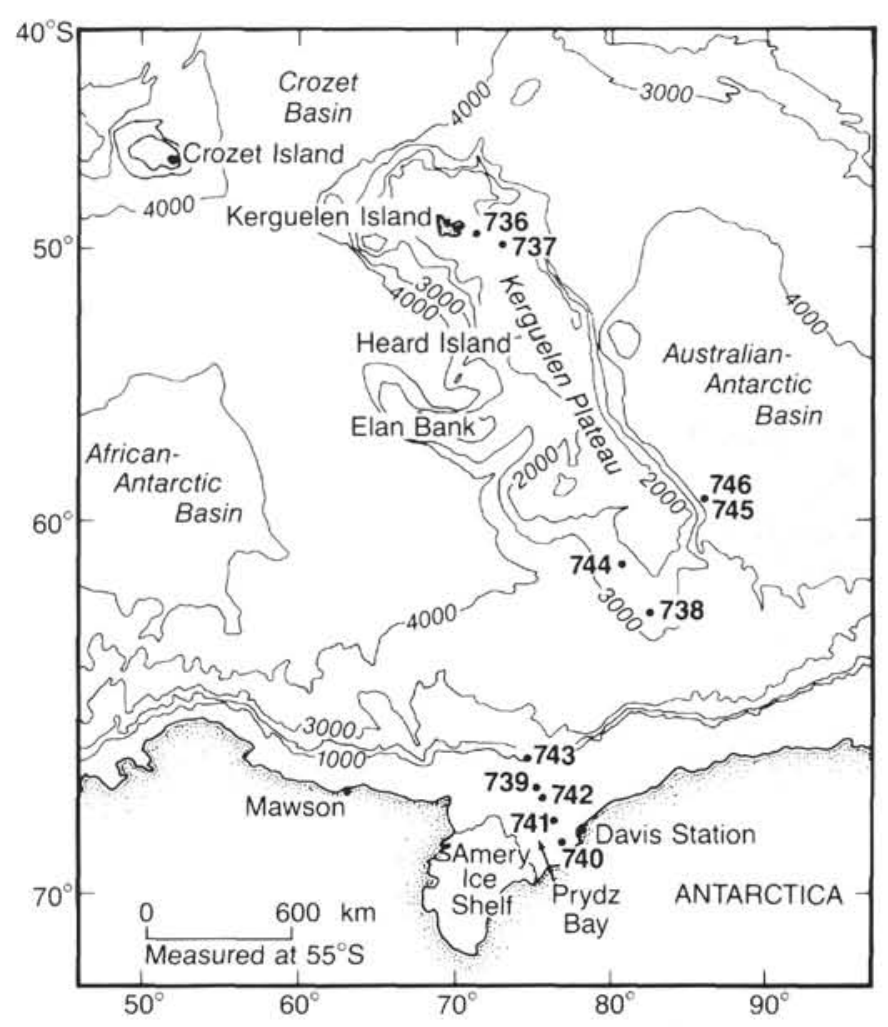

Figure 1. Locations of holes drilled during Leg 119 (from Barron, Larsen, et al., 1989).

The primary drilling objective at Prydz Bay was to determine the glacial history of Antarctica through the timing and nature of the initiation of the ice sheet. Previous results obtained by Leg 113 (Leg 113 Shipboard Scientific Party, 1987) in the Weddell Sea indicate that the glaciation at sea level first occurred during the late early Oligocene on East Antarctica. At Hole $742 \mathrm{~A}\left(67.55^{\circ} \mathrm{S} / 75.41^{\circ} \mathrm{E}\right)$, the sediments of the deep continental shelf were drilled. They include an older diamictite sequence 
that contains middle Eocene to Oligocene nannofossils. The magnetostratigraphy of this sequence may be used to determine whether the initiation of the ice sheet occurred during the Oligocene or Eocene.

\section{METHODS}

Paleomagnetic measurements were made from both wholecore and discrete samples.

Oriented discrete samples from the soft sediments were collected by pressing the plastic cubes $\left(7 \mathrm{~cm}^{3}\right.$ in volume) into them. For the limestone sequence at Hole $738 \mathrm{C}$ and for the sedimentary sequence at Hole $742 \mathrm{~A}$, samples were cut using a stainlesssteel knife or by diamond saw and placed into the cube.

Measurement of the remanence in discrete samples on shore was made by either the cryogenic magnetometers (CCL GM-401 of Toyama University or ScT type of National Institute of Polar Research in Japan) or the Schonstedt spinner magnetometer (SSM-1) of University of Washington. Remanence stability was examined mainly by alternating field (AF) demagnetization method. AF demagnetization of the samples was made as follows. At each hole, about $20 \%$ of the samples were chosen as a pilot sample. They were AF demagnetized systematically in steps of $5 \mathrm{mT}$ at least up to $40 \mathrm{mT}$. Then, the characteristic direction for each sample was determined by the diagonal vector analysis (Zijderveld, 1967). Some samples from the limestone sequence in Hole $738 \mathrm{C}$ were subjected to the stepwise thermal demagnetization. Whole-core pass-through cryogenic (WCC) system on shipboard has not been effective before Leg 119. The ODP technicians (J. Tauxe and others) and the authors corrected the operation system which became available from Hole $738 \mathrm{C}$. The highest AF (alternating field) demagnetization field available in the system was up to $9 \mathrm{mT}$. The measurement with the WCC system was made on the archive halves of cores from Holes 738C, 742A, 745B, and 746A.

Results obtained by WCC system, in most cases, were consistent as compared with the data obtained from the discrete samples of the same core region. The difference between WCC data and discrete data appeared sometimes in the regions containing the strongly magnetized conglomerates. In these regions, WCC data did not provide reliable results and were not used.

The initial susceptibility was measured on the samples from Holes 742A and 745B with the Bartington MS-1 magnetic-susceptibility meter on board and ashore. The results were compared with the lithological change. The whole-core susceptibility was measured by MS-1 susceptibility meter on the sequence around Cretaceous/Tertiary boundary of Hole $738 \mathrm{C}$ on board.

To determine the magnetostratigraphy in Cenozoic section (Holes 737A, 745B, and 746A), the time scale by Berggren et al. (1985) was used, augmented by the time scale by McDougall (1979) and Mankinen and Cox (1988) referred for the subchrons (the Cobb Mountain, Gilsa, and Reunion Subchrons) not included in the time scale by Berggren et al. (1985). Table 1 shows their time scales between Brunhes chron and Chron C5.

Altogether, the paleomagnetic data from 856 discrete samples are utilized in this study.

\section{RESULTS AND DISCUSSION}

\section{Hole 745B}

At Hole 745B, the diatom ooze sediment was cored with the advanced hydraulic piston corer (APC) down to $167 \mathrm{mbsf}(\mathrm{m}$ below seafloor). Discrete samples were taken in $30-50 \mathrm{~cm}$ spacing. NRM intensities of them range from 0.8 to $28.8 \mathrm{~mA} / \mathrm{M}$. Most of them are relatively strong, on the order of $10 \mathrm{~mA} / \mathrm{M}$. Figure 2 shows the examples of AF demagnetization experiments. Similar to these results, most of the samples have the high mean destructive AF field (MDF; $~ 30 \mathrm{mT}$ ) and has the little overprinting in NRM. The recovery ratio of the cores and
Table 1. Polarity time scale used in this study.

\begin{tabular}{|c|c|c|c|c|}
\hline Chron & Subchrons & $\begin{array}{l}\mathrm{Age}^{\mathrm{a}} \\
\text { (Ma) }\end{array}$ & $\begin{array}{l}\mathrm{Age}^{\mathrm{b}} \\
(\mathrm{Ma})\end{array}$ & $\begin{array}{l}\mathrm{Age}^{\mathrm{c}} \\
\text { (Ma) }\end{array}$ \\
\hline Brunhes & & & $0-0.73$ & \\
\hline \multirow[t]{7}{*}{ Matuyama } & & & $0.73-2.47$ & \\
\hline & Jaramillo & $0.89-0.94$ & $0.90-0.97$ & $0.91-0.98$ \\
\hline & Cobb Mountain & & 1.10 & \\
\hline & Gilsa & 1.62 & & \\
\hline & Olduvai & $1.76-1.91$ & $1.67-1.87$ & $1.66-1.88$ \\
\hline & Renunion & $2.07-2.23$ & $2.01-2.04$ & \\
\hline & & & $2.12-2.14$ & \\
\hline \multirow[t]{2}{*}{ Gauss } & & $2.47-3.40$ & & \\
\hline & Kaena & $2.91-3.00$ & $\begin{array}{l}2.92-3.01 \\
3.05-3.15\end{array}$ & $2.92-2.99$ \\
\hline \multirow[t]{5}{*}{ Gilbert } & Mammoth & $3.07-3.17$ & $3.40-5.35$ & $3.08-3.18$ \\
\hline & Cochiti & $3.82-3.92$ & $3.80-3.90$ & $3.88-3.97$ \\
\hline & Nunivak & $4.07-4.25$ & $4.05-4.20$ & $4.10-4.24$ \\
\hline & Sidufjalll & $4.44-4.57$ & $4.32-4.47$ & $4.40-4.47$ \\
\hline & Thvera & $4.72-4.94$ & $4.85-5.00$ & $4.57-4.77$ \\
\hline \multirow{4}{*}{ Chron C $3 \mathrm{~A}$} & & & $5.35-6.70$ & \\
\hline & $\mathrm{C} 3 \mathrm{AN}-1$ & & $5.35-5.53$ & \\
\hline & C3AN-2 & & $5.68-5.89$ & \\
\hline & C3AN-3 & & $6.37-6.50$ & \\
\hline \multirow[t]{4}{*}{ Chron $\mathrm{C} 4$} & & & $6.70-7.90$ & \\
\hline & $\mathrm{C} 4 \mathrm{~N}-1$ & & $6.70-6.78$ & \\
\hline & $\mathrm{C} 4 \mathrm{~N}-2$ & & $6.85-7.28$ & \\
\hline & $\mathrm{C} 4 \mathrm{~N}-3$ & & $7.35-7.41$ & \\
\hline \multirow[t]{4}{*}{ Chron C4A } & & & $7.90-8.92$ & \\
\hline & C4AN-1 & & $7.90-8.21$ & \\
\hline & $\mathrm{C} 4 \mathrm{AN}-2$ & & $8.41-8.50$ & \\
\hline & C4AN-3 & & $8.71-8.80$ & \\
\hline \multirow[t]{4}{*}{ Chron C5 } & & & $8.92-11.55$ & \\
\hline & $\mathrm{C} 5 \mathrm{~N}-1$ & & $8.92-10.42$ & \\
\hline & $\mathrm{C} 5 \mathrm{~N}-2$ & & $10.54-10.59$ & \\
\hline & $\mathrm{C} 5 \mathrm{~N}-3$ & & 11.03 & 11.09 \\
\hline
\end{tabular}

Note: In the column of subchron and its age of older than Chron C3A, normal polarity zones are shown.

a McDougall (1979).

b Mankinen and Cox (1988).

c Berggren et al.(1985).

biostratigraphy age control were good. Reliable paleomagnetic data were obtained from 375 discrete samples.

The polarity sequence of Hole 745B (Fig. 3) is compared with the time scale in Table 1 . The possible polarity interpretation is attempted by referring the biostratigraphic age. The Brunhes/Matuyama Chronozone boundary $(0.73 \mathrm{Ma})$ is identified at 42.6 mbsf. Referring to the diatom event of D8 (2.49 Ma) (see Barron et al., this volume) around $110 \mathrm{mbsf}$, the sequence below this boundary down to 112.3 mbsf characterized by reversal polarity is assigned to the Matuyama Chron $(0.73 \sim 2.47 \mathrm{Ma})$. In the Matuyama chron, five normal zones, "a" from 50.4 to 54.3 mbsf, "b" around $56.8 \mathrm{mbsf}$, "c" from 89.3 to $89.8 \mathrm{mbsf}$, "d" from 91.8 to $93.3 \mathrm{mbsf}$, and "e" from 99.3 to $99.8 \mathrm{mbsf}$, are identified.

Normal zones "a" and " $d$ " are identified by more than four discrete samples, however, zones "b," "c," and "e" are identified by one or two samples. Because of the sparse data, there is a possibility that the normal polarities in these regions are obtained by the mistake in sampling. To check this, the WCC data are compared. Figures $4 \mathrm{~A}, 4 \mathrm{~B}$, and $4 \mathrm{C}$ represent the inclinations by WCC measurement around the zones "b," "c," and "e," respectively. They were measured at $5 \mathrm{mT}$ AF demagnetization step with a $10-\mathrm{cm}$ spacing. Each normal zone identified by WCC measurements contains more than five data points, i.e., the length of each normal zone is over $50 \mathrm{~cm}$. Thus, the WCC data confirm the normal polarity zones of "b," "c," and "e." Polarity assignment of the five normal zones in Matuyama Chron is attempted.

Referring to the biostratigraphic age, the zones " $a$ " and " $d$ " in Figure 3 are correlated to the Jaramillo and Olduvai Subchrons, respectively. The zone "c" located above the Olduvai 

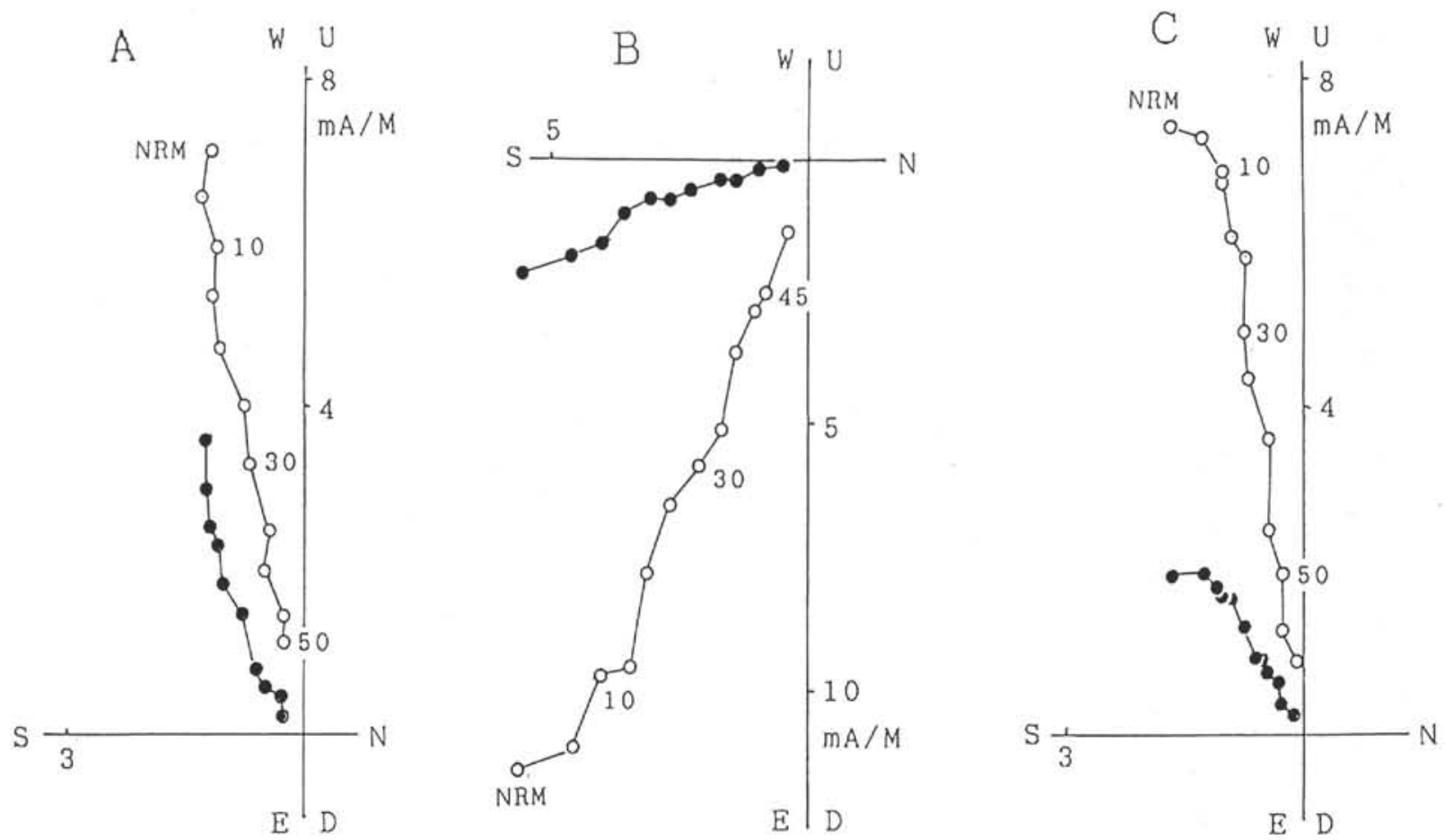

Figure 2. Representative orthogonal vector plots of demagnetization curves of samples from Hole 745B. Filled circles show the projection of the magnetic vector on the horizontal plane; open circles represent the projection of the vector on the north-south vertical plane. Small numbers in figures are the AF demagnetization step in mT. A. Sample 119-745B-3H-1, $114 \mathrm{~cm}$. B. Sample 119-745B-9H-2, $30 \mathrm{~cm}$. C. Sample 119-745B-19H-4, $94 \mathrm{~cm}$.

Subchron $(1.16 \sim 1.88 \mathrm{Ma})$ is correlated to the Gilsa Subchron. The normal zone "e" below Olduvai Subchron may be correlated to the Reunion Subchron. In the WCC data, the zone "e" is split to three normal zones. We did not get adequate discrete samples in this region. More detailed sampling and the analysis are necessary for the study of Reunion Subchron in this region. The normal polarity zone "b" is situated shortly below Jaramillo Subchron $(0.91 \sim 0.98 \mathrm{Ma})$. It may be correlated to the "Cobb Mountain Event" of an age around 1.1 Ma (Mankinen et al., 1978). This event was first found in the volcanic rocks from the northern California, however, it has been rarely observed in the deep sea core studies (Bleil, 1989).

In the biostratigraphic study, the radiolarian event R6 (3.2 $\mathrm{Ma}$ ) around $131 \mathrm{mbsf}$ was identified (Barron et al., in this volume). Referring to it, a normal polarity zone from 112.8 to 132.8 mbsf is assigned to the Gauss Chron $(2.47 \sim 3.40 \mathrm{Ma})$ and the two reversed zones in this chron are correlated to the Mammoth and Kaena Subchrons.

The continuous magnetic polarity pattern and the biostratigraphy correlation such as the diatom event of D15 (5.1 Ma) around 180 mbsf indicate that the sequence from 186.2 to 133.3 mbsf corresponds to the Gilbert reversed chron $(3.40 \sim 5.35$ $\mathrm{Ma}$ ). In this sequence, five normal polarity zones are identified. Each zone contains more than three stable inclination points. The five normal zones in Gilbert Chron were also reported at Hole 642B drilled in the Norwegian Sea (Bleil, 1989). However, the existing geomagnetic polarity time scales show four normal subchrons in Gilbert chron (Table 1). We compared the polarity sequence from 133.3 to 186.2 mbsf with the representative time scales (Fig. 5). Comparing the two representative time scales (Berggren et al., 1985, and Mankinen and Cox, 1988), the large difference in the age of Thvera subchron becomes apparent. The age of Thvera (Berggren et al., 1985) is about 0.3 Ma younger than the age by Mankinen and Cox (1988). The large age difference for the Thvera subchron suggests the possibility that there are two different subchrons in the age of the formerly assigned Thvera subchron.

In the polarity interpretation of our results, three upper normal zones may be reasonably assigned to Cochiti, Nunivak, and Sidufjall Subchrons, respectively. Concerning the other two normal zones, we assigned the zone between 167.6 and $166.5 \mathrm{mbsf}$ to Thvera subchron by Mankinen and Cox (1988) and the zone between 180.3 and 178.8 mbsf to Thvera subchron by Berggren et al. (1985). The curve of Hole 745B in Figure 10 shows the changes of the estimated age vs. depth by this interpretation. The curve of sedimentation rate in the Gilbert Chron (3.40-5.35 $\mathrm{Ma}$ ) is smoothly connected to the upper and lower sequences, which may support our polarity interpretation.

Thus, Hole $745 \mathrm{~B}$ provides the magnetostratigraphy suggesting the five normal subchrons in Gilbert Chron and that the formerly assigned Thvera Subchron consists of two different subchrons.

\section{Hole 746A}

After the drilling was terminated at Hole 745B because of an approaching iceberg, the drilling at Hole $746 \mathrm{~A}$ was made about $5 \mathrm{~km}$ north of Hole 745B on the same sedimentary ridge. APC cores were taken from 164.8 to 227.3 mbsf and then the hole was XCB cored to 280.8 mbsf. The sedimentary sequence consists of silty clay diatom ooze. NRM intensity of the discrete samples ranges from 0.1 to $8.4 \mathrm{~mA} / \mathrm{M}$. Overprinting magnetic component existed in NRM, however, they were removed by $\mathrm{AF}$ demagnetization in most of the samples (Fig. 6). Stable magnetization are obtained from 123 discrete samples.

In Figure 7, stable inclinations are plotted against depth. The depth of $188.4 \mathrm{mbsf}$ is assigned to be the base of Chron C3A $(6.70 \mathrm{Ma})$, based on the biostratigraphy age such as the diatom event D4 (6.4 Ma) around 172 mbsf (Barron et al., this volume). Although no discrete samples were obtained from the area around 210 mbsf, WCC data at $5 \mathrm{mT}$ AF show a clear normal polarity 

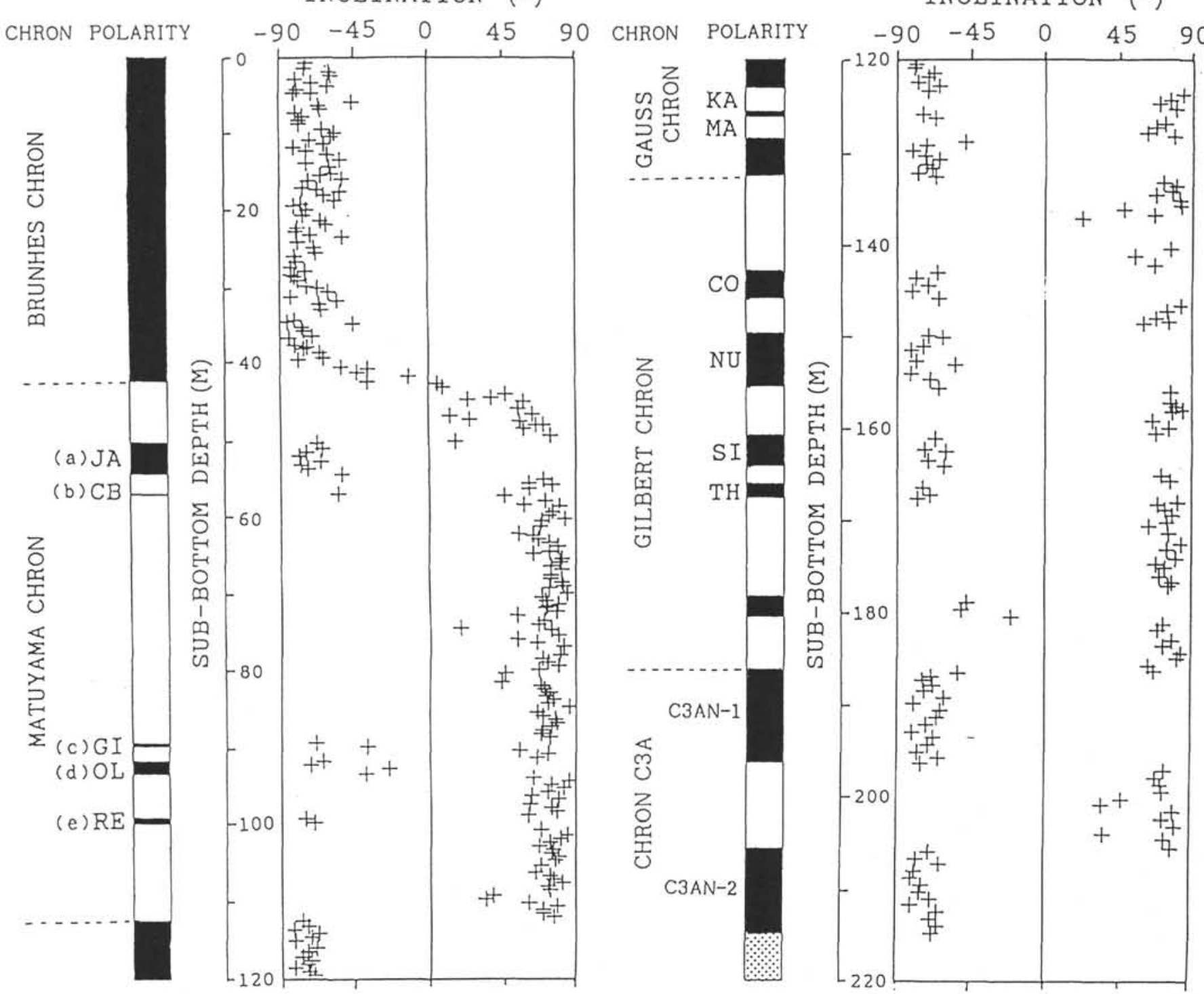

Figure 3. Plot of magnetic inclination after AF treatment and polarity interpretation of Hole 745B vs. depth. Black and white indicate normal and reversed polarity, respectively; the dotted pattern indicates gaps in the record. Subchrons: (a) JA = Jaramillo; (b) CB = Cobb Mountain; (c) GI = Gilsa; (d) $\mathrm{OL}=$ Olduvai; (e) $\mathrm{RE}=$ Reunion; $\mathrm{KA}=$ Kaena; $\mathrm{MA}=$ Mammoth; $\mathrm{CO}=$ Cochiti; $\mathrm{NU}=$ Nunivak; $\mathrm{SI}=\mathrm{Sidufjall}$; $\mathrm{TH}=\mathrm{Thvera}$.

in this region (Figure 4D). Referring the diatom event D8 (7.4 $\mathrm{Ma}$ ) around $203 \mathrm{mbsf}$, this normal polarity zone is assigned to subchron of $\mathrm{C} 4 \mathrm{~N}-3(7.35 \sim 7.41 \mathrm{Ma})$. Then, three normal polarity regions from 228 to 189 mbsf are exactly correlated to the subchrons in Chron C4 $(6.70 \sim 7.90 \mathrm{Ma})$. Referring the diatom event of D12 (8.4 Ma) around $236 \mathrm{mbsf}$, the sequence under 243 mbsf is assigned to Chron C5 $(8.92 \sim 11.55 \mathrm{Ma})$.

\section{Hole 737A}

At Hole $737 \mathrm{~A}$, drilling was by APC down to $167 \mathrm{mbsf}$, and then the sequence from 167 to 237.2 mbsf was cored with the extended core barrel (XCB). The diatom nannofossil ooze sediments were drilled.

Figure 8 shows the examples of AF demagnetizations. NRM intensities range from 0.1 to $32.3 \mathrm{~mA} / \mathrm{M}$ and most of them are weak, on the order of $1 \mathrm{~mA} / \mathrm{M}$. The MDF value is about $20 \mathrm{mT}$ on average. Most of the samples have overprinting component in NRM's which are eliminated by AF demagnetization (Figs. $8 \mathrm{~B}$ and $8 \mathrm{C}$ ). Several samples have multi magnetic components in
NRM's and we could not get the primary component from them (Fig. 8A).

Figure 9 shows the downward change of magnetic inclinations after AF demagnetization with depth and the identified polarity. The possible polarity interpretation was attempted. Referring to the biostratigraphic data (Barron et al., this volume) such as diatom events of D14 $(6.3 \mathrm{Ma})$ around $240 \mathrm{mbsf}$, the normal polarity zone below 234 mbsf is assigned to Chron 4 . Diatom event of D12 (5.8 Ma) is identified around $155 \mathrm{mbsf}$, and the dominant normal zone from 164 to 129 mbsf is correlated to Chron 3A (5.35-6.70 Ma). The dominant reversal sequence above 129 mbsf with the four normal subchrons is assigned to Gilbert Chron. The core recovery from 220 to 165 mbsf is bad, and we could not correlate this region to the standard polarity sequence.

Figure 10 shows the sedimentation rate for the Holes $737 \mathrm{~A}$, $745 \mathrm{~B}$, and 746A. The polarity sequence of Mankinen and Cox (1988) is used to assign the ages to Reunion, Cobb Mountain Subchrons in the Matuyama Chron, and for the subchrons in 
A

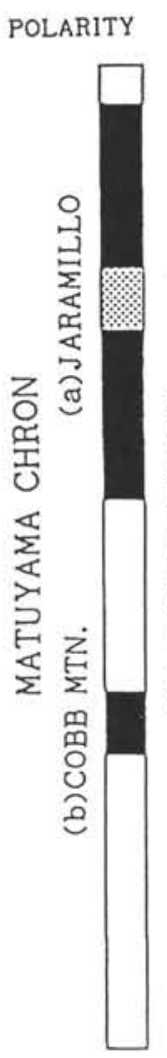

POLARITY

INCLINATION ( $\left.{ }^{\circ}\right)$

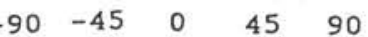

\begin{tabular}{r|rr}
-90 & -45 & 0 \\
\hline
\end{tabular}

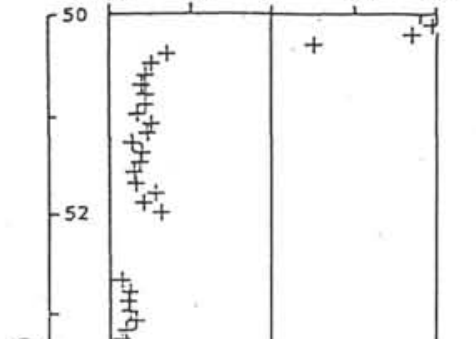

POLARITY

B

INCLINATION (०)

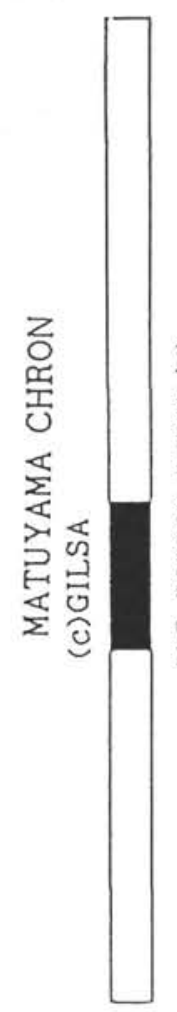

$\begin{array}{rrrrr}-90 & -45 & 0 & 45 & 90\end{array}$

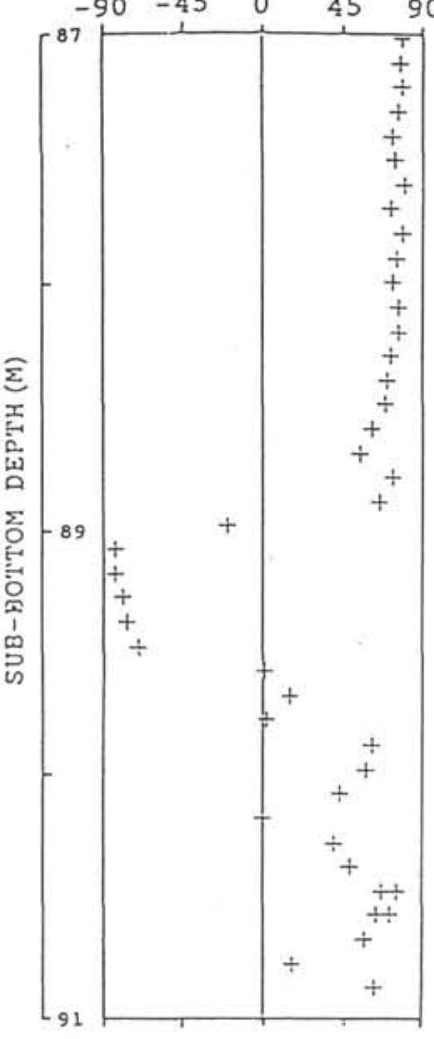

INCLINATION $\left({ }^{\circ}\right)$

POLARITY

$\mathrm{C}$

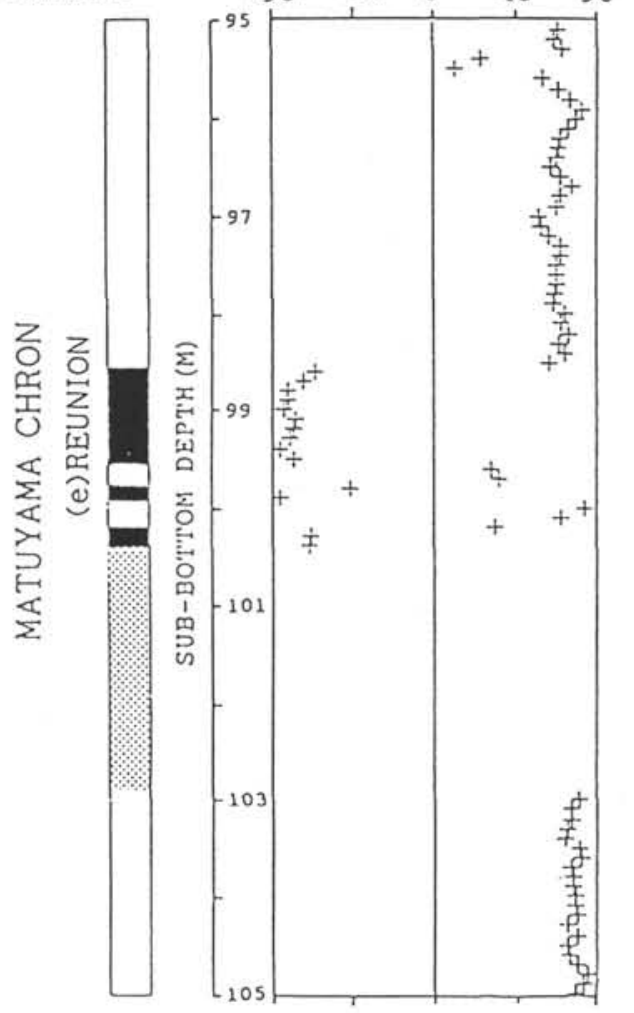

POLARITY

D

INCLINRTION (०)
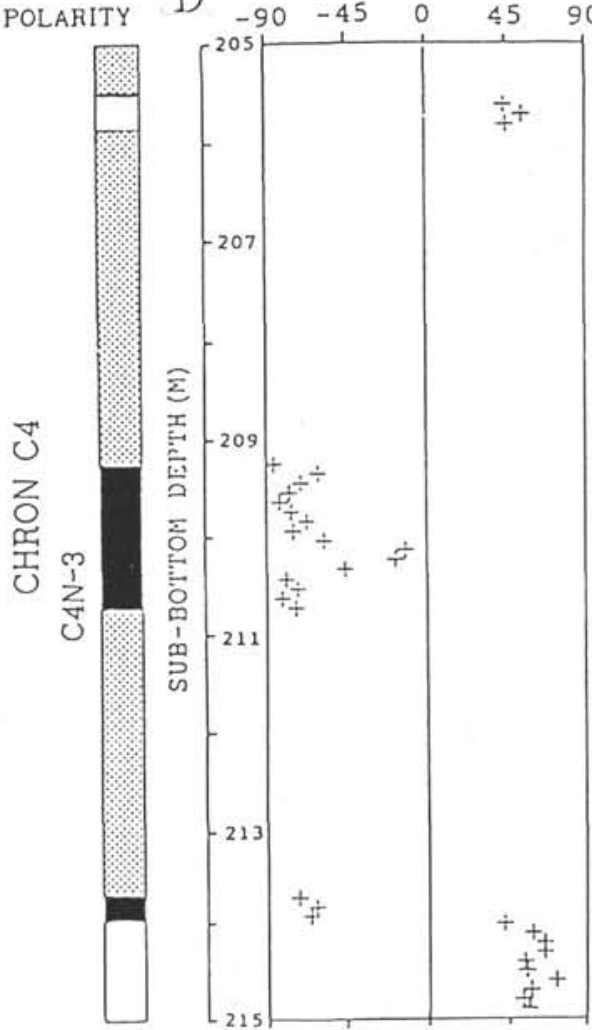

Figure 4. Profiles of magnetic inclination measured by the whole core cryogenic magnetometer after 9-mT AF demagnetization. The polarity interpretation and the name of corresponding subchron is shown on the left. Marked regions of (a) to (e) correspond to these in Figure 3, respectively. A. Subchrons Jaramillo and Cobb Mountain, 50-60 mbsf, Hole 745B. B. Subchron Gilsa, 87-91 mbsf, Hole 745B. C. Subchron Reunion, 95-105 mbsf, Hole 745B. D. Anomaly 4A, 87-91 mbsf, Hole 746A. 


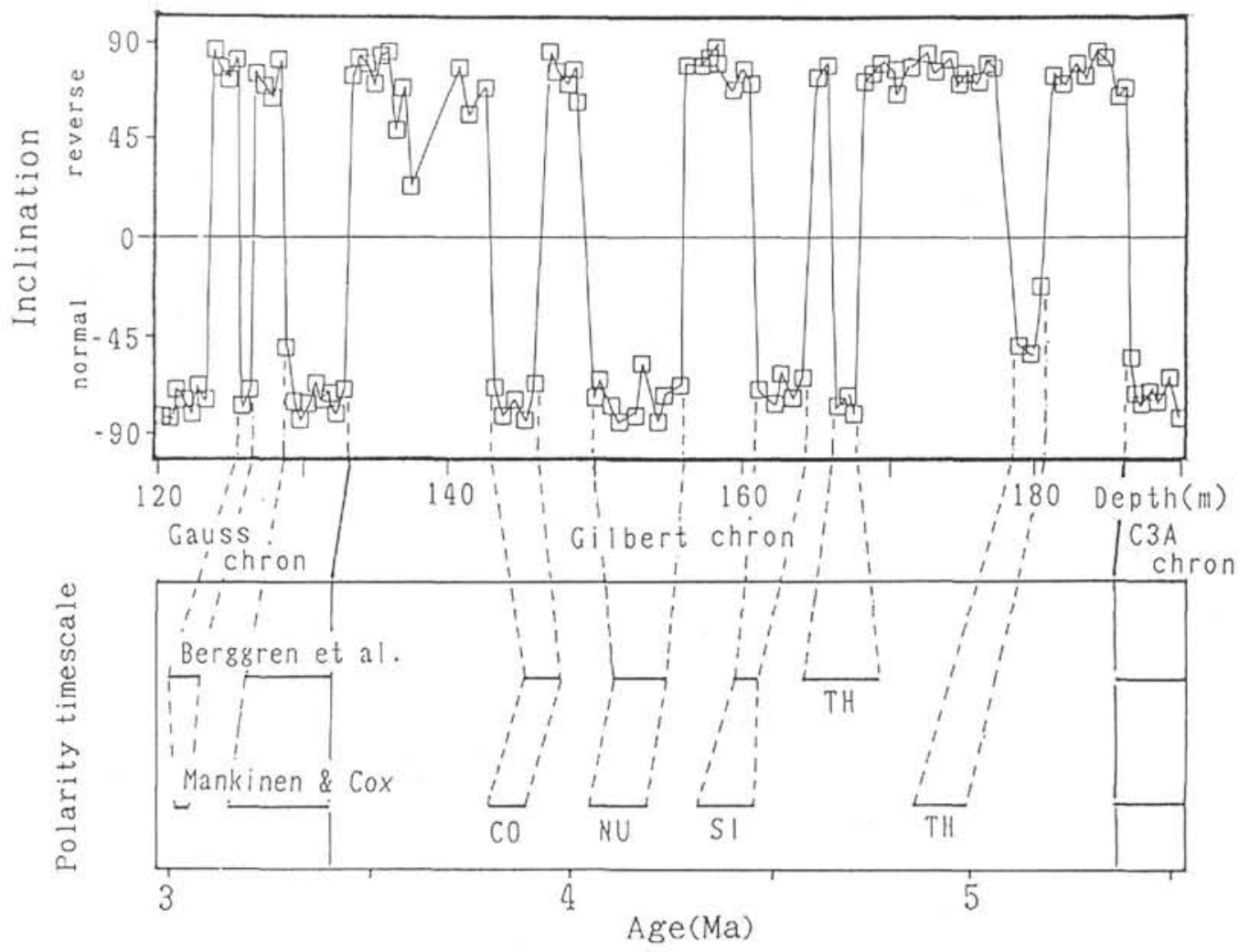

Figure 5. Plot of magnetic inclination after AF treatment and polarity interpretation of the sequence between 190 and 120 mbsf of Hole 745B. Subchrons: $\mathrm{TH}=$ Thvera; $\mathrm{SI}=$ Sidufjall; $\mathrm{NU}=$ Nunivak; $\mathrm{CO}=\mathrm{Cochiti}$. The time scales referred to are from Berggren et al. (1985) and from Mankinen and Cox (1988).
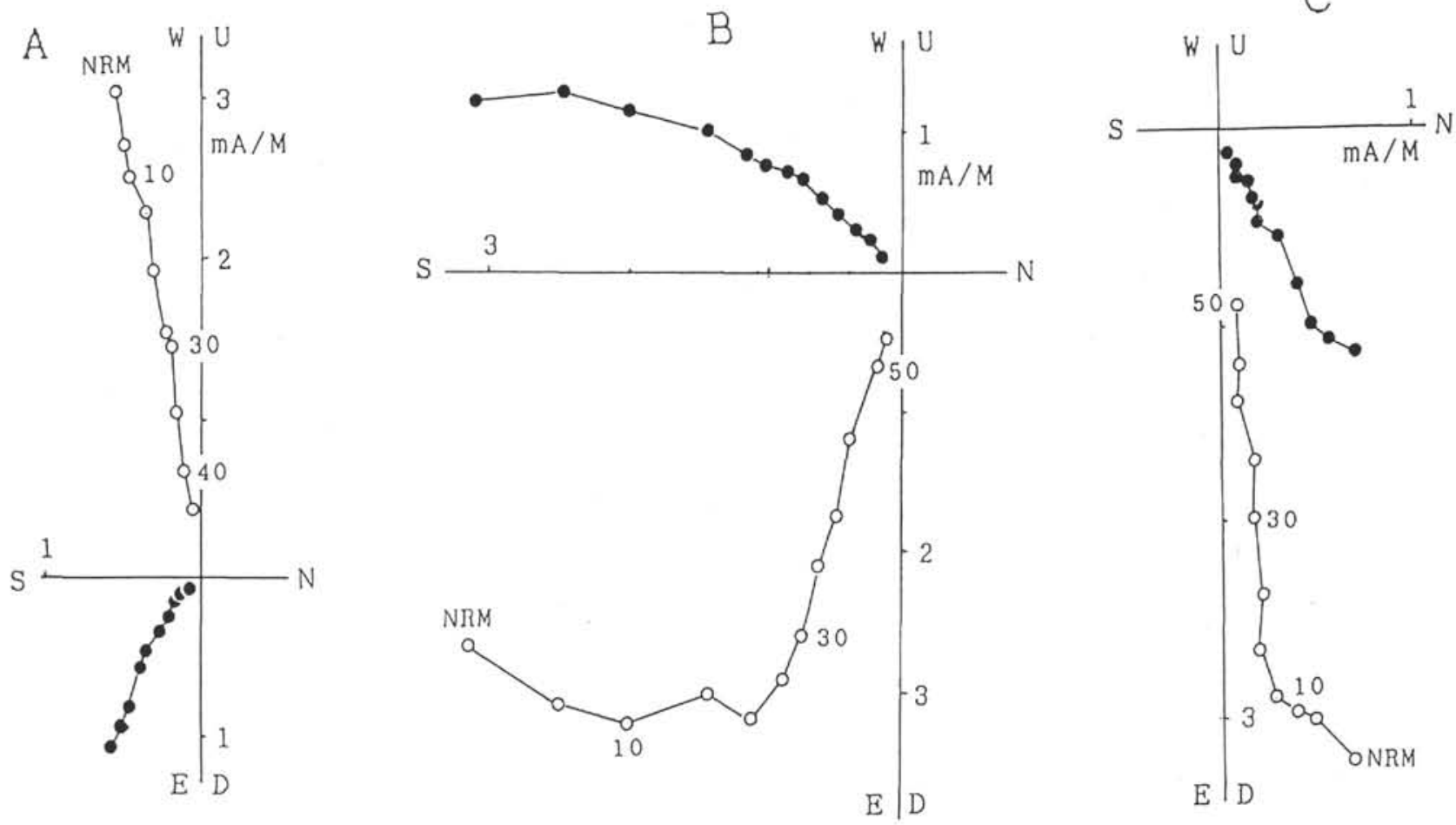

Figure 6. Representative orthogonal vector plots of demagnetization curves of samples from Hole 746A. A. Sample 119-746A-6H-6, 63 cm. B. Sample 119-746A-10H-1, $109 \mathrm{~cm}$. C. Sample 119-746A-11X-6, $80 \mathrm{~cm}$. In most samples, overprinting component is little. Conventions as Figure 2. 
INCLINATION $\left({ }^{\circ}\right)$

INCLINATION $\left({ }^{\circ}\right)$

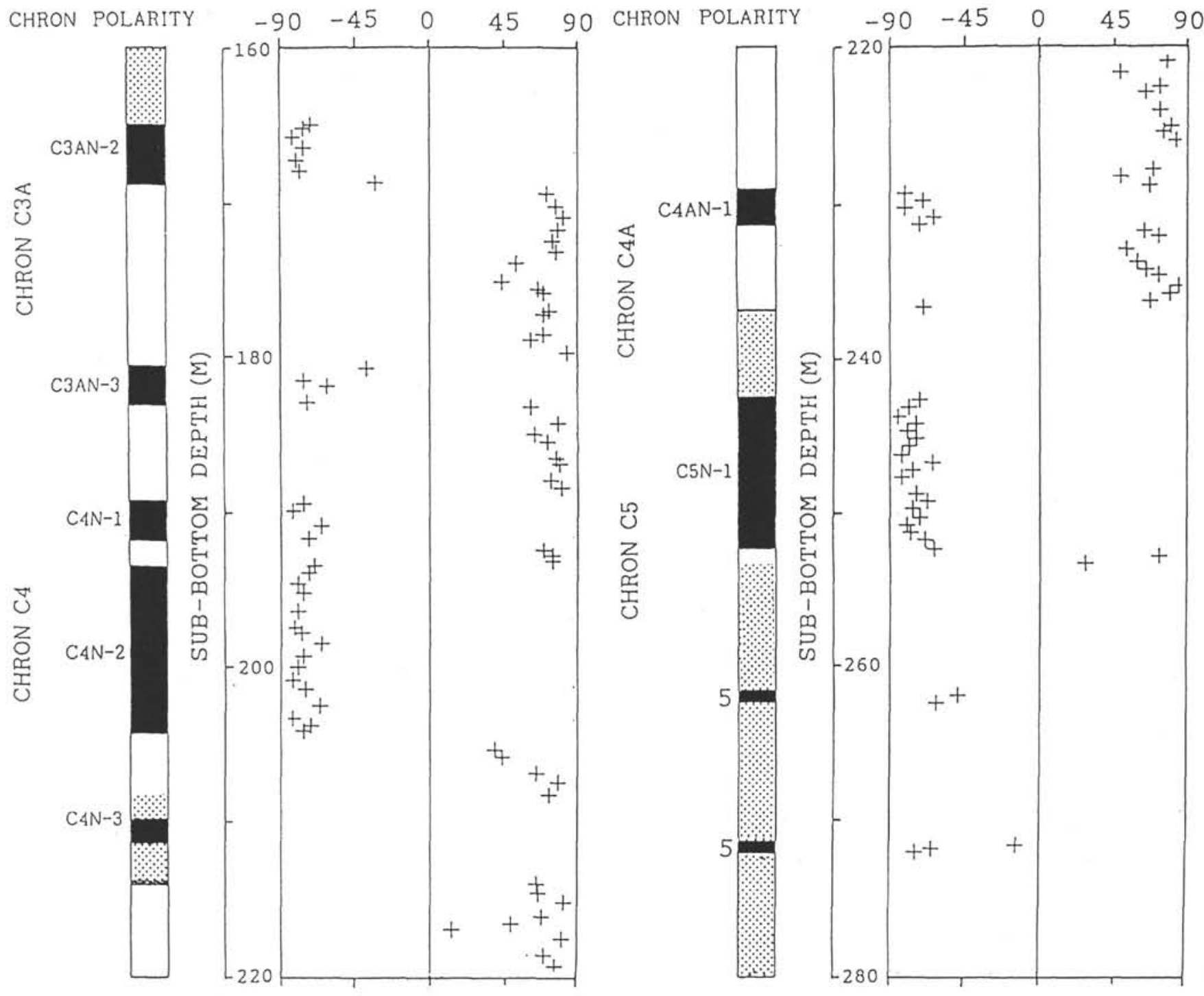

Figure 7. Magnetic inclination after AF treatment and polarity interpretation of Hole $746 \mathrm{~A}$ vs. depth. Chrons and subchrons are referred from Table 1. The normal polarity Subchron C4N-3 around $210 \mathrm{mbsf}$ is identified by WCC data in Figure 4D. Conventions as Figure 3.

the Gilbert Chron. For the Gilsa Subchron in Matuyama Chron, the age by MacDougall (1979) is referenced. Other zones are assigned using the time scale of Berggren et al. (1985). The sedimentation rate in each hole is generally smooth. There is no overlap between the cored section in Holes 745B and 746A. The depth to the sediment around $6 \mathrm{Ma}$ in Hole 745B is about $30 \mathrm{~m}$ lower than that of Hole 746A. The sedimentation rate of Hole $737 \mathrm{~A}$ on north Kerguelen is about three times higher $(84 \mathrm{~m} / \mathrm{Ma})$ than the rate estimated from Holes $745 \mathrm{~B}$ and $746 \mathrm{~A}$ on south Kerguelen Plateau.

\section{Susceptibility, NRM Intensities, and MDF's of Hole 745B}

Figure 11 shows the change of NRM intensities, susceptibilities, and MDF values with depth downhole. Scatter of the data is large, however, the following features are recognizable. A good correlation exists between the change of NRM intensities and that of susceptibilities. Scatter in both groups seems to decrease below 120 mbsf. There is a broad peak around 60,120 , and 180 mbsf.
Lithological studies found an increase in the amount of icerafted material in the intervals of $80-40$ mbsf and $200-160$ mbsf (Barron, Larsen, et al., 1989) indicating the enhanced glaciation in the early Pliocene and Quaternary. In each interval, the MDF's are almost constant (Fig. 11C), which suggests that the change of magnetic minerals during the enhanced glaciation is not serious. A broad peak in the NRM intensities and susceptibilities in each region may be caused by an increase in magnetic minerals within the ice-rafted material.

A short hiatus was identified around 120 mbsf, 3 Ma (Barron, Larsen, et al., 1989). The MDF value of the sequence below 120 mbsf is about $5 \mathrm{mT}$ higher than that of the upper sequence in average. The change in MDF values above the hiatus may be caused by the change of the lithology, which also is due to the larger scattering of the magnetic properties above the hiatus.

\section{Hole $738 \mathrm{C}$}

A paleomagnetic study at Hole $738 \mathrm{C}$ was done on the limestone sequence from 479.7 to $418.6 \mathrm{mbsf}$ and the calcareous 

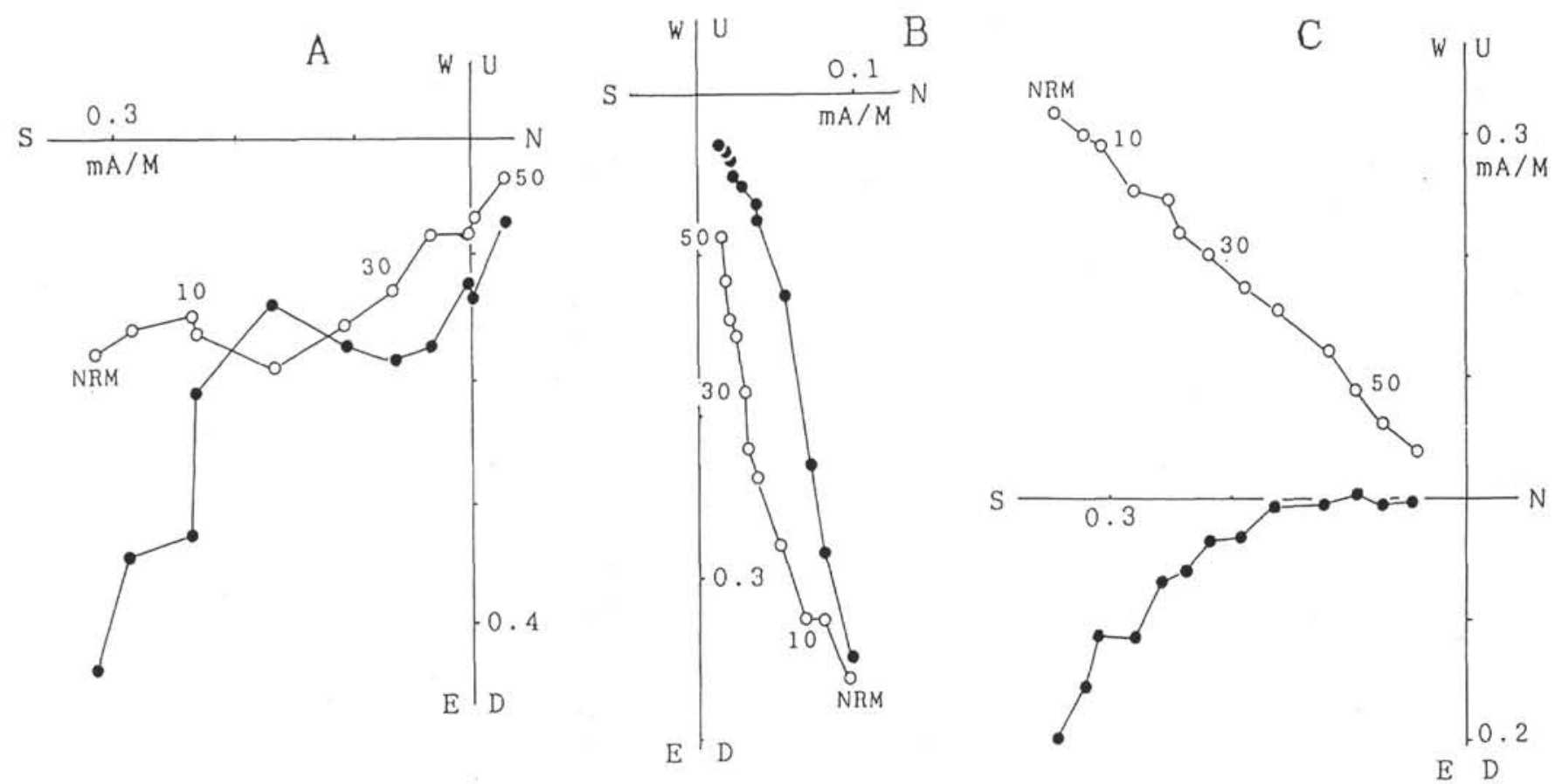

Figure 8. Representative orthogonal vector plots of demagnetization curves of samples from Hole 737A. A. Sample 119-737A-3H-5, 16 cm. B. Sample 119-737A-7H-4, $98 \mathrm{~cm}$. C. Sample 119-737A-17H-4, $43 \mathrm{~cm}$. Conventions as Figure 2.

chalk sequence from 418.6 to 360 mbsf drilled by the RCB (rotary core barrel).

A complete, undisturbed Cretaceous/Tertiary boundary section was drilled in Section 119-738C-20R-5 between 377.4 and $376.2 \mathrm{mbsf}$. The Cretaceous/Tertiary boundary was determined based on biostratigraphy and iridium concentration anomaly. The boundary was placed at about 377.15 mbsf within an interval of laminated claystone about $15 \mathrm{~cm}$ thick (Thierstein et al., this volume).

Discrete samples were not obtained around the Cretaceous/ Tertiary boundary. Figure $12 \mathrm{~A}$ is the AF demagnetization result of Sample 119-738C-20R-4, $108 \mathrm{~cm}$ (about $110 \mathrm{~cm}$ above the boundary) which shows the reversed polarity. As shown in Figure 13, both the stable inclinations around 379.9 mbsf, below the Cretaceous/Tertiary boundary, and the data between 376.3 and $375.8 \mathrm{mbsf}$, above the boundary, show reversed magnetic polarity. A reversed polarity at the Cretaceous/Tertiary boundary has been found at DSDP Site 577 (Wright et al., 1985) and is expected from the time scale of Berggren et al. (1985). Therefore, we can correlate the reversed interval between 375.8 and 379.9 mbsf to the reversed Chron C29R. Based on the nannofossil data, the sequence around $362 \mathrm{mbsf}$ may be correlated to reversed Chron C27R.

Figures 14A and 14B show the change of WCC remanent intensity in the archive half of Section 119-738C-20R-5 before AF demagnetization and at the $5 \mathrm{mT}$ AF demagnetization step, respectively. Figure $14 \mathrm{C}$ shows the change of magnetic susceptibility measured with a $2.5-\mathrm{cm}$ spacing on the same core. The three plots in Figures 14 have a similar trend in the region above 377 mbsf and below 377.2 mbsf. We can identify a broad peak at about 376.85 mbsf. The lithological study (Barron, Larsen, et al., 1989) shows the increment of clay minerals in this region. The broad maximum of intensity and susceptibility around 376.85 mbsf could reflect the contribution from clay minerals. The largest difference of the three figures is between 377.1 and 377.2 mbsf. The broad NRM intensity and the subpeak in susceptibil- ity are at about $377.15 \mathrm{mbsf}$, however, intensity after $5 \mathrm{mT}$ AF is quite weak. These results suggest that the sequence around 377.15 mbsf has a soft magnetization component with high susceptibility.

The core depth of 377.15 mbsf is a region of green clay, $3 \mathrm{~mm}$ thick. At this depth in the core, the iridium analysis (Schmidt et al., this volume) showed high iridium concentration. Worm and Banerjee (1987) showed the correlation between a high susceptibility and iridium concentration about the Cretaceous/Tertiary boundary in several DSDP cores from Pacific Ocean. They also showed that the magnetization of the sediments at the high susceptibility region has a soft component, possibly caused by a multidomain microspherules. Our results from the Southern Indian Ocean support the correlation of the high susceptibility and iridium concentration at the Cretaceous/ Tertiary boundary. The high susceptibility and the soft magnetic component obtained in this study may also be caused by the presence of unstable magnetic minerals, such as black microspherule as shown by Worm and Banerjee (1987).

\section{Cretaceous Sequence}

At Hole $738 \mathrm{C}$, the lower Turonian to Campanian silicified limestone between 479.7 and $418.6 \mathrm{mbsf}$ and the Campanian to Maestrichtian calcareous chalk between 418.6 and 390 mbsf were sampled. Figures 12B-12D show an AF and thermal stability test made on the pilot samples. Similar to the results of Figures $12 \mathrm{C}$ and $12 \mathrm{D}$, the samples from 480 to 440 mbsf have the stable remanences. Analysis of planktonic foraminifers suggests the existence of a hiatus above 410 mbsf (Huber, this volume). The NRM's of the sequence from 403 to 390 mbsf have the larger overprinting component (Fig. 12B). Paleomagnetic data were obtained from 74 samples.

The limestone sequence below $430 \mathrm{mbsf}$ is assigned to the Santonian by the analysis of the nannofossils. The normal zone below 438.2 mbsf in Figure 13 is correlated to Chron C34 (Kent and Gradstein, 1985). The normal polarity sequence from 412 


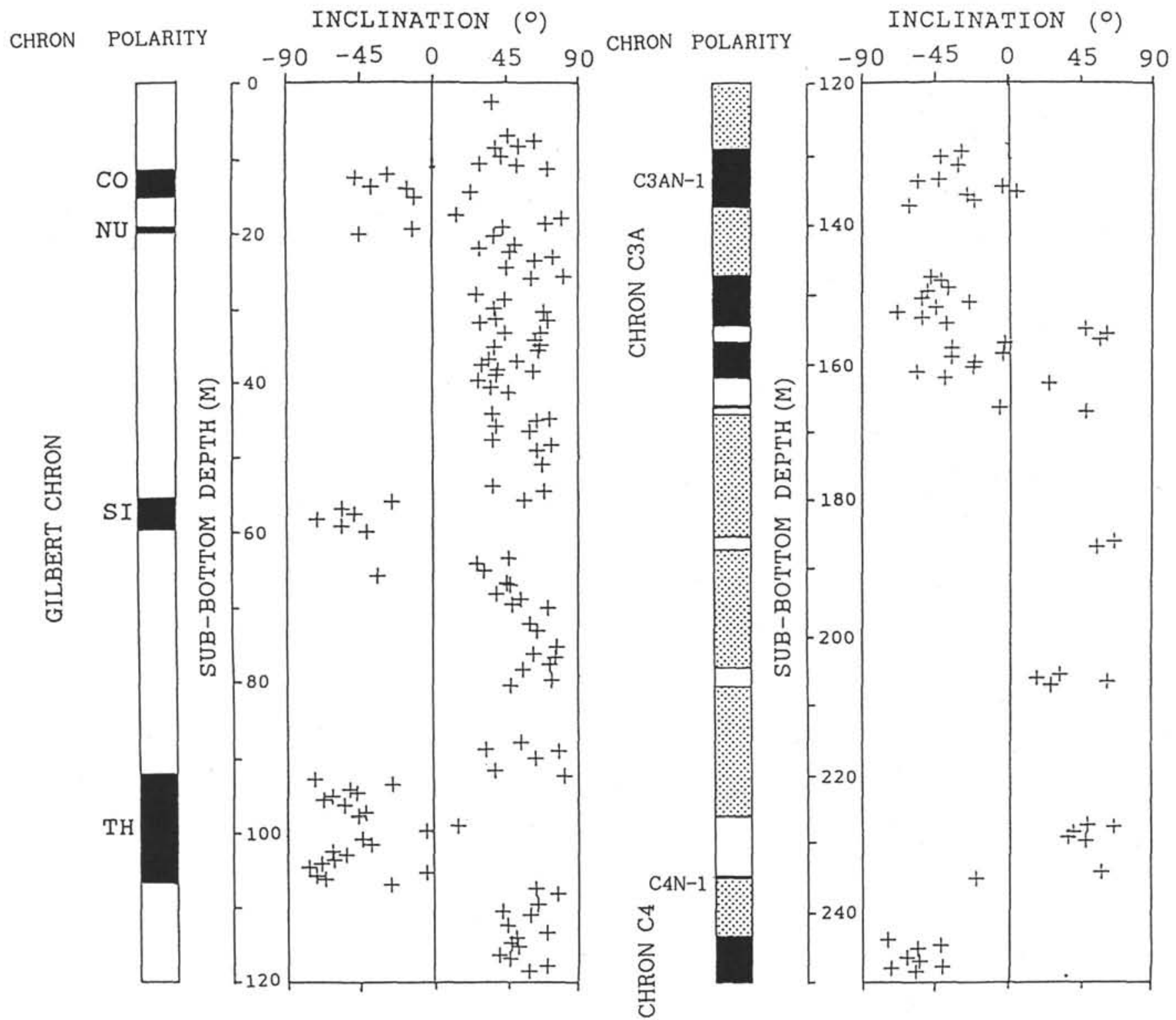

Figure 9. Magnetic inclination after AF treatment and polarity interpretation of Hole 737A vs. depth. Subchrons: $\mathrm{CO}=\mathrm{Cochiti}$; $\mathrm{NU}=$ Nunivak; SI $=$ Sidufjall; $\mathrm{TH}=$ Thvera. Conventions as Figure 3.

to 410 mbsf may be correlated to Chron $\mathrm{C} 32 \mathrm{~N}$, based on the biostratigraphic data such as nannofossil event N19 and the event of planktonic foraminifer FAD of Abathomphalus mayaroensis ( $<71 \mathrm{Ma})$ around 410 mbsf (Barron et al., this volume).

The stable magnetization of the limestone sequence (ca. 90$70 \mathrm{Ma}$ ) between 480 and $440 \mathrm{mbsf}$ is used to estimate the paleolatitude. The mean inclination (Fig. 15) is calculated as $70.6^{\circ} \pm$ $6.8^{\circ}$ by the method of McFadden and Reid (1982), which corresponds to the paleolatitude of $53.9^{\circ} \pm 8.8^{\circ} \mathrm{S}$.

The estimated paleolatitude is shallower than the latitude of $63^{\circ} \mathrm{S}$ for this hole calculated from the geomagnetic dipole. This paleolatitude was compared to the paleomagnetic poles from East Antarctica. As shown in Figure 16, the paleomagnetic poles of East Antarctica available for our study are only obtained for the upper Tertiary and Jurassic and not for Cretaceous (McElhinny, 1973; Funaki, 1984). The calculated latitude for Hole $738 \mathrm{C}$ using the Jurassic pole of Antarctica yielded $32^{\circ} \mathrm{S}$ and that of the upper Tertiary was $54^{\circ} \mathrm{S}$. The Tertiary latitude is almost the same as the paleolatitude $54^{\circ} \mathrm{S}$ at Hole $738 \mathrm{C}$.

The equality of the Santonian paleolatitude with that cr the late Tertiary implies that Hole $738 \mathrm{C}$ has remained at the presentday location in relation to Antarctica since the late Cretaceous.

\section{Hole 742A}

At Hole $742 \mathrm{~A}$ in Prydz Bay, a sediment sequence was obtained by RCB coring down to 316 mbsf. Most of the sediments are diamictites and diamicton.

The limited biological data indicate that the age of the sequence above 172.5 mbsf is assigned to be from Quaternary to Pliocene, and the sequence between $\mathbf{1 7 2 . 5}$ and $313.3 \mathrm{mbsf}$ is assigned to be middle Eocene to Oligocene. The left figure in Figure 17 shows the variation of NRM intensity and susceptibility with depth. The abrupt changes in susceptibility are observed in several intervals of the sequence. These changes correlate well 


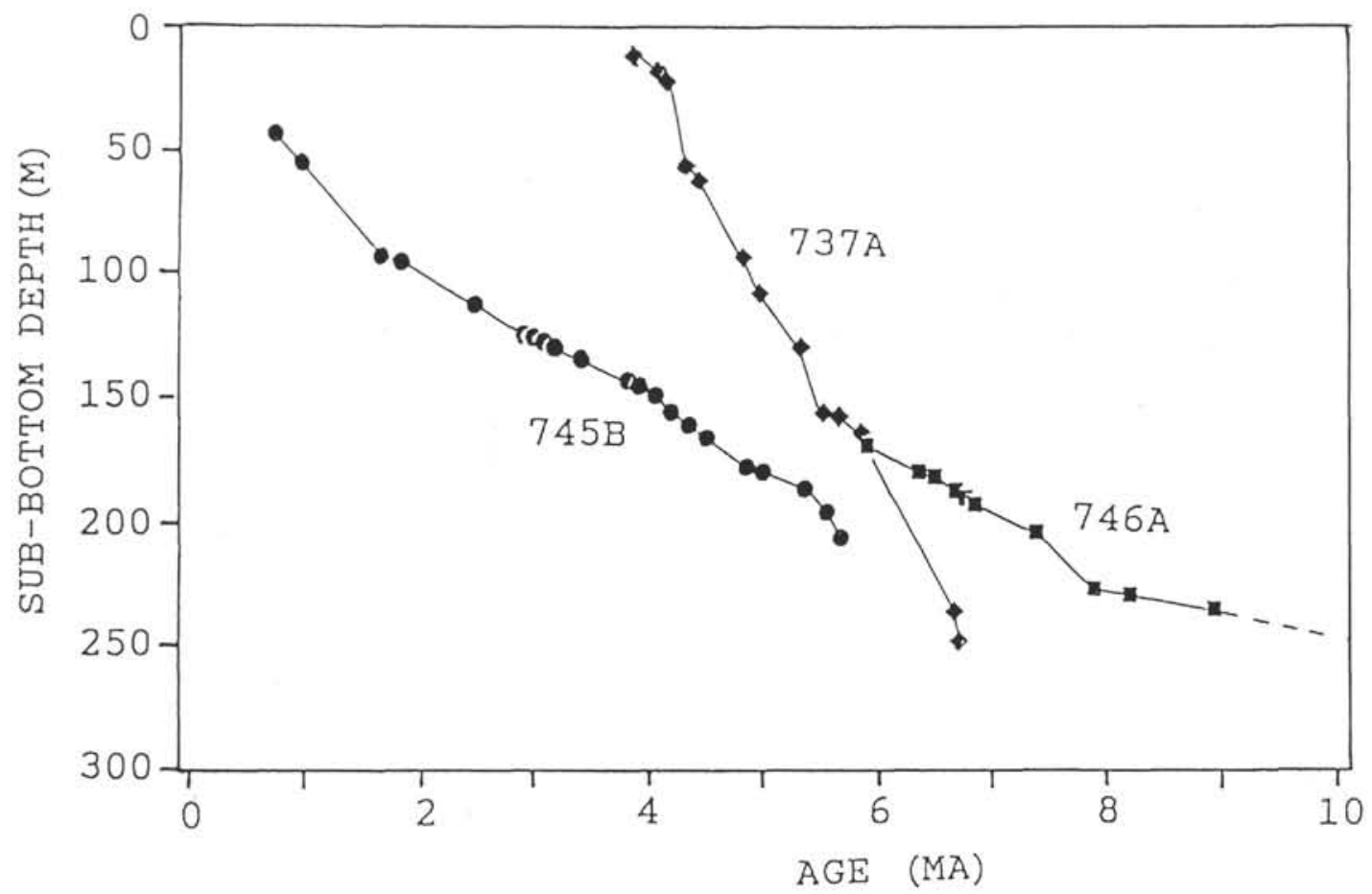

Figure 10. Age vs. depth profile of Holes 737A, 745B, and 746A. The time scale of Berggren et al. (1985) was mainly used for the magnetostratigraphic interpretation. At Hole 745B, the time scale of Mankinen and Cox (1988) was used for the Cobb Mountain and Reunion Subchrons in Matuyama Chron and the subchrons in Gilbert Chron. The time scale of McDougall (1979) was used for the Gilsa Subchron in Matuyama Chron.

with the locations of lithology changes. The clearest change occurs at about $\mathbf{1 7 2 . 5}$ mbsf. Above 172.5 mbsf, a clear stepwise decreasing trend is shown in the susceptibility. Below $172.5 \mathrm{mbsf}$, both the change in NRM intensity and susceptibility show a similar small change.

The magnetization above $172.5 \mathrm{mbsf}$ is unstable (Fig. 18A), and the MDF values are between 5 and $12 \mathrm{mT}$. The sequence above 172.5 mbsf contains large amounts of coarse-grained conglomerates. The different trend in susceptibility and NRM intensity above 172.5 mbsf may be caused by the presence of large magnetic minerals in the coarse-grained conglomerate with high susceptibility and unstable NRM. The abrupt change in susceptibility and NRM intensity suggests that some environmental change may have taken place at Prydz Bay between Oligocene and Pliocene.

Figures $18 \mathrm{~B}$ and $18 \mathrm{C}$ show the results of $\mathrm{AF}$ demagnetization experiments on two samples from the sequence below $170 \mathrm{mbsf}$. Similar to the examples, the magnetization of the sequence below 170 mbsf is generally stable. This sequence consists of homogeneous diamictite with lower gravel content and includes many carbonate-cemented layers. Figure 19 shows the characteristic inclinations after AF demagnetization obtained from 89 discrete samples and the WCC data at $9 \mathrm{mT}$ AF. Both data show that this sequence is dominantly normally magnetized. Several brief intervals of reversed polarity are concordant between the discrete data and WCC data. The restricted biostratigraphy data shows this sequence is from middle Eocene to Oligocene. The polarity time scale (Berggren et al., 1985) in the right of Figure 19 shows that the sequence between Anomalies 18 and 15 (42.7$38.8 \mathrm{Ma}$ ) is dominantly normally magnetized with several short reversed zones. In the case of the sequence below $172.5 \mathrm{mbsf}$ at Hole $742 \mathrm{~A}$, the assignment to this polarity sequence may be plausible, which suggests the existence of glacial complex in Prydz Bay possibly during late middle Eocene time. We have not done the rock magnetic study on these sediments yet, and the possi- bility remains that this sequence of dominant normal polarity has been remagnetized. To confirm the observed polarity sequence, further rock magnetic study may be necessary.

\section{CONCLUSIONS AND SUMMARY}

The paleomagnetic results obtained in this study are summarized as follows.

1. The magnetostratigraphy of the late Miocene to Quaternary was obtained from the Holes 737A, 745B, and 746A drilled on the Kerguelen Plateau. Based on the excellent quality magnetostratigraphy at Hole $745 \mathrm{~B}$, the confirmation of the Cobb Mountain Subchron in the Matuyama Chron and existence of previously unidentified subchron in the Gilbert Chron are suggested.

2. At Hole $738 \mathrm{C}$, a complete, undisturbed Cretaceous/Tertiary boundary section was drilled. Susceptibility data show high values at the boundary region, which correlates with the high susceptibility at boundary region found in the Pacific Ocean by Worm and Banerjee (1987). The Turonian to Santonian limestone sequence shows stable and concordant inclination. The calculated paleolatitude of $54^{\circ} \mathrm{S}$ is about $10^{\circ}$ lower than the present-day latitude and nearly same as that of the late Tertiary as calculated from the paleomagnetic pole of Antarctica.

3. The magnetic susceptibility measured for the glacial sequence at Hole 742A of Prydz Bay showed a good correlation with the change in lithology. The stable inclinations obtained from the discrete samples and whole core cryogenic data at $9 \mathrm{mT}$ AF suggest that the sequence from middle Eocene to Oligocene has a dominantly normal polarity with several short reversed polarity zones.

\section{ACKNOWLEDGMENTS}

We would like to thank to Dr. J. Barron, Dr. J. Baldauf, and Dr. B. T. Huber, who kindly assisted the stratigraphic work with 
A

INTENSITY (NRM)

$(\mathrm{mA} / \mathrm{M})$

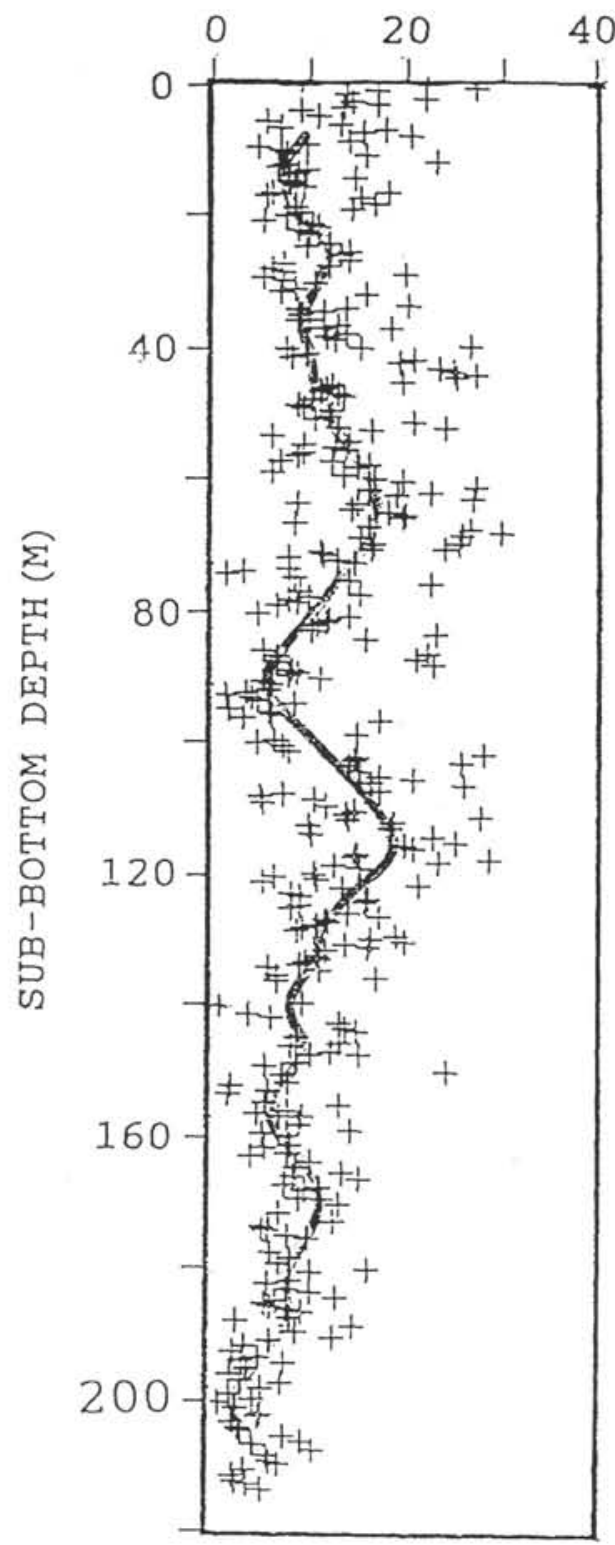

B

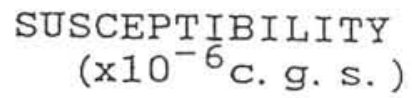

$C$

$\mathrm{MDF}(\mathrm{mT})$

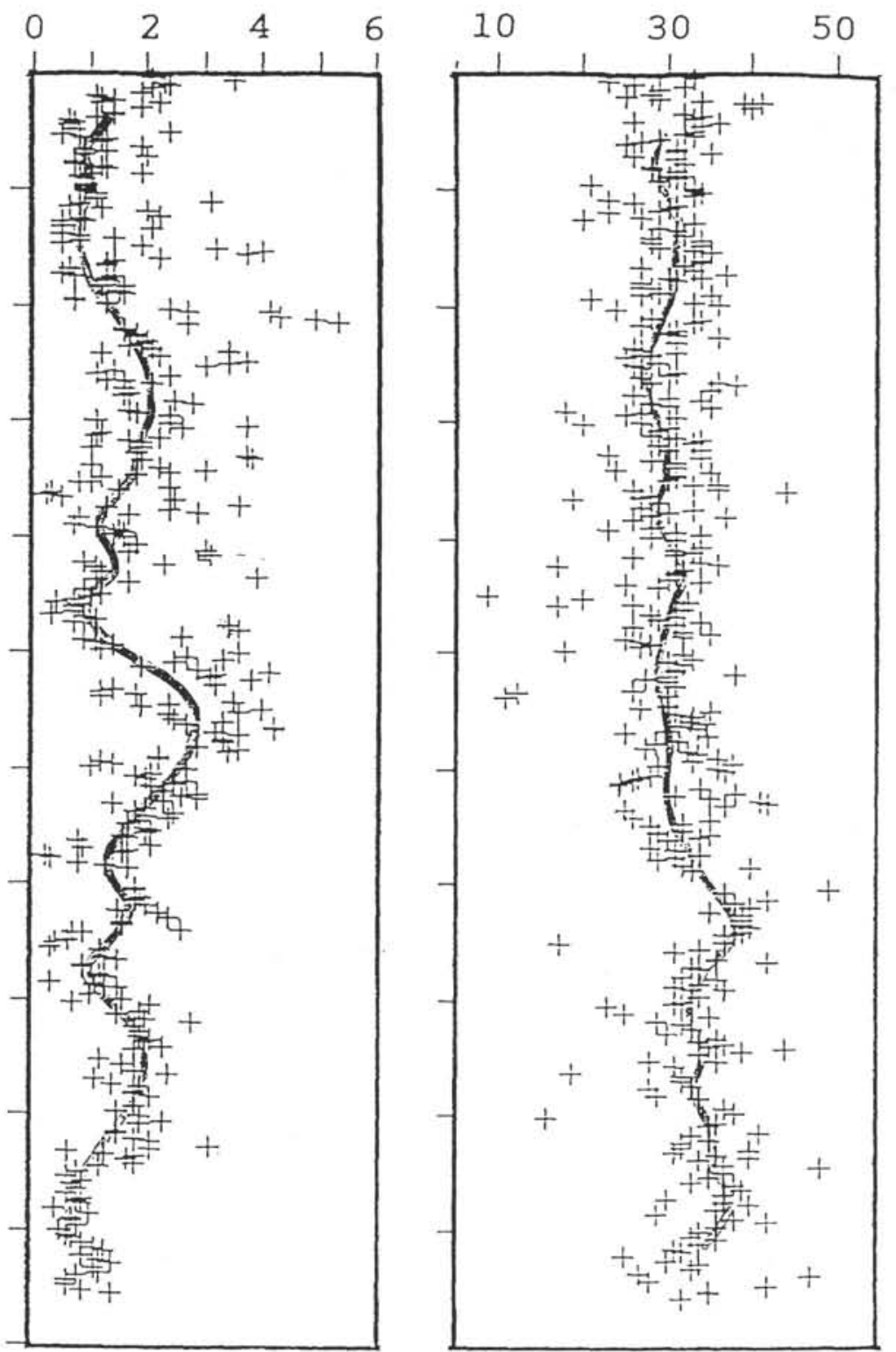

Figure 11. Downhole variation of (A) NRM intensity, (B) magnetic susceptibility, and (C) MDF value, Hole 745B. Averaged curves of the variation of each data are also shown.

their biostratigraphic data. The author (H.S.) gratefully says thanks to Dr. H.P. Johnson and Dr. M. Funaki for their valuable discussion and advice.

\section{REFERENCES}

Barron, J., Larsen, B., et al., 1989. Proc. ODP, Init. Repts., 119: College Station, TX (Ocean Drilling Program).

Berggren, W. A., Kent, D. V., Flynn, J. J., and Van Couvering, J. A., 1985. Cenozoic geochronology. Geol. Soc. Am. Bull., 96:1407-1418. Bleil, U., 1989. Magnetostratigraphy of Neogene and Quaternary sediment series from the Norwegian Sea: Ocean Drilling Program, Leg 104. In Eldholm, O., Thiede, J., Taylor, E., et al., Proc. ODP, Sci. Results, 104: College Station, TX (Ocean Drilling Program), 829901.
Coffin, M. F., Davies, H. L., and Haxby, W. F., 1986. Structure of the Kerguelen Plateau province from SEASAT altimetry and seismic reflection data. Nature, 324:134-136.

Funaki, M., 1984. Paleomagnetic investigation of McMurdo Sound region, southern Victoria Land, Antarctica, Mem. Natl. Inst. Polar Res. Ser C., 16:1-81.

Houtz, R. E., Hayes, D. E., and Markl, R. G., 1977. Kerguelen Plateau bathymetry, sediment distribution and crustal structure. Mar. Geol., 25:95-130.

Kent, D. V., and Gradstein, F. M., 1985. A Cretaceous and Jurassic geochronology. Geol. Soc. Am. Bull., 96:1419-1427.

Leg 113 Shipboard Scientific Party, 1987. Glacial history of Antarctica. Nature, 328:115-116.

Mankinen, E. A., and Cox, A., 1988. Paleomagnetic investigation of some volcanic rocks from the McMurdo volcanic province, Antarctica. J. Geophys. Res., 93:11599-11612. 
Mankinen, E. A., Donnelly, J. M., and Gromm, C. S., 1978. Geomagnetic polarity event recorded at 1.1. m.y.r. B.P. on Cobb mountain, Clear Lake volcanic field, California. Geology, 6:653-656.

McDougall, I., 1979. The present status of the geomagnetic polarity timescale. In McElhinny, M. W. (Ed.), The Earth: Its Origin, Evolution and Structure: London (Academic Press), 543-566.

McElhinny, M. W., 1973. Palaeomagnetism and Plate Tectonics: Cambridge (Cambridge Univ. Press).

McFadden, P. L., and Reid, A. B., 1982. Analysis of paleomagnetic inclination data. Geophys. J. R. Astron. Soc., 69:307-319.

Munschy, M., and Schlich, R., 1987. Structure and evolution of the Kerguelen-Heard Plateau (Indian Ocean) deduced from seismic stratigraphy studies. Mar. Geol., 76:131-152.

Worm, H. U., and Banerjee, S. K., 1987. Rock magnetic signature of the Cretaceous-Tertiary boundary, Geophys. Res. Lett., 14, 10831086 .
Wright, A. A., Bleil, U., Monechi, S., Michel, H. V., Shackleton, N. J., Simoneit, B.R.T. and Zachos, J. C., 1985. Summary of Cretaceous/ Tertiary boundary studies, Deep Sea Drilling Project Site 577, Shatsky Rise. In Heath, G. R., Burckle, L. H., et al., Init. Repts. DSDP, 86: Washington (U.S. Govt. Printing Office), 799-804.

Zijderveld, J.D.A., 1967. A.C. demagnetization of rocks:. analysis of results. In Collinson, D. W., Creer, K. M., Runcorn, S. K., (Eds.), Methods in palaeomagnetism: Amsterdam (Elsevier), 254-286.

Date of initial receipt: 19 December 1989

Date of acceptance: 25 July 1990

Ms 119B-150 

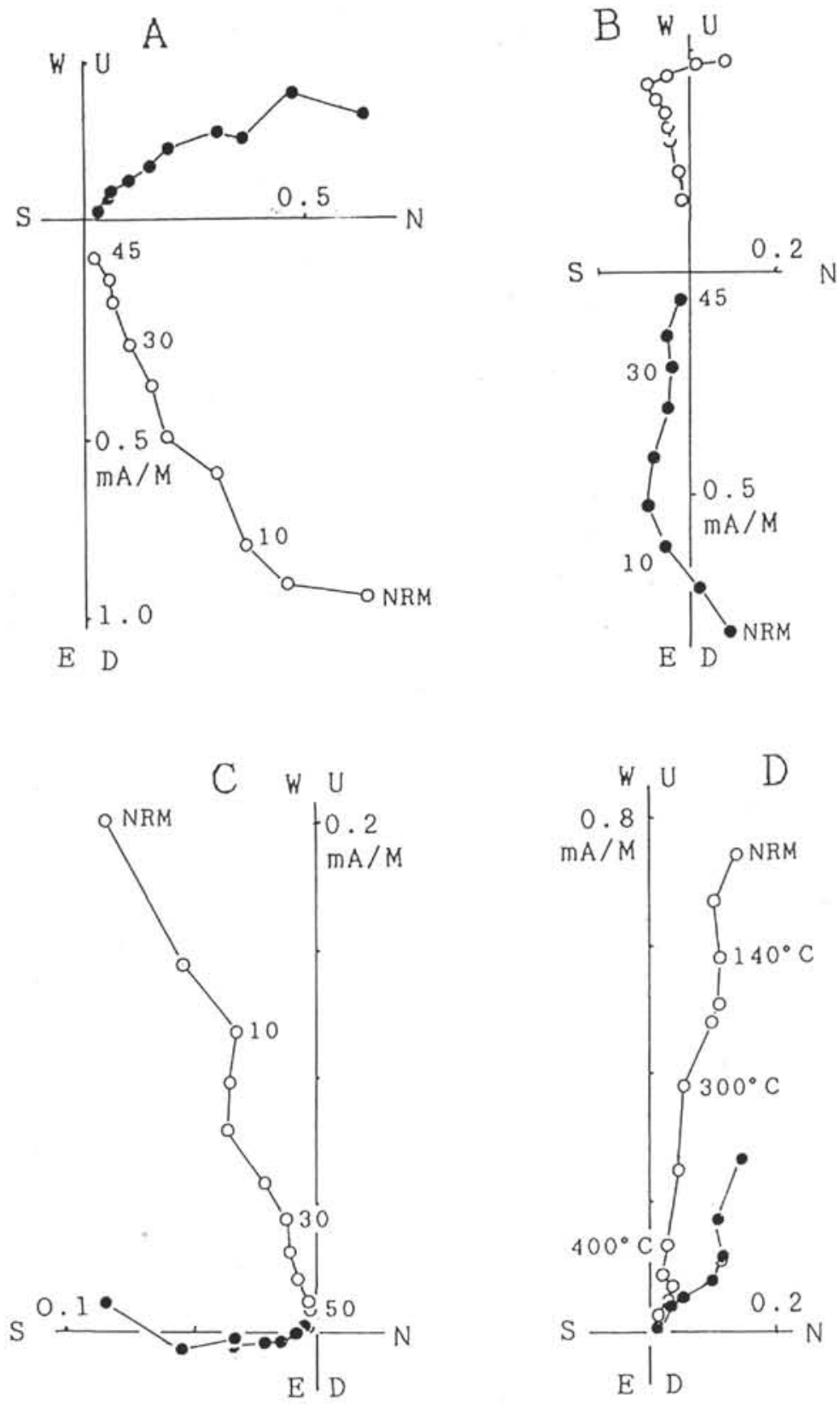

Figure 12. Representative orthogonal vector plots of demagnetization curves of samples from Holes 738C. Open circles show the projection of the magnetic vector on the horizontal plane; closed circles represent the projection of the vector on the north-south vertical plane. Small numbers in Figures 12A, 12B, and $12 \mathrm{C}$ are the AF demagnetization step in $\mathrm{mT}$; in Figure 12D they denote temperature step. A. Sample 119-738C-20R-4, $108 \mathrm{~cm}$; AF demagnetization. B. Sample 119-738C-22R-5, $27 \mathrm{~cm}$; AF demagnetization. C. Sample 119-738C-27R-1, $30 \mathrm{~cm}$; AF demagnetization. D. Sample 119-738C-31R-1, $48 \mathrm{~cm}$; TH demagnetization. 


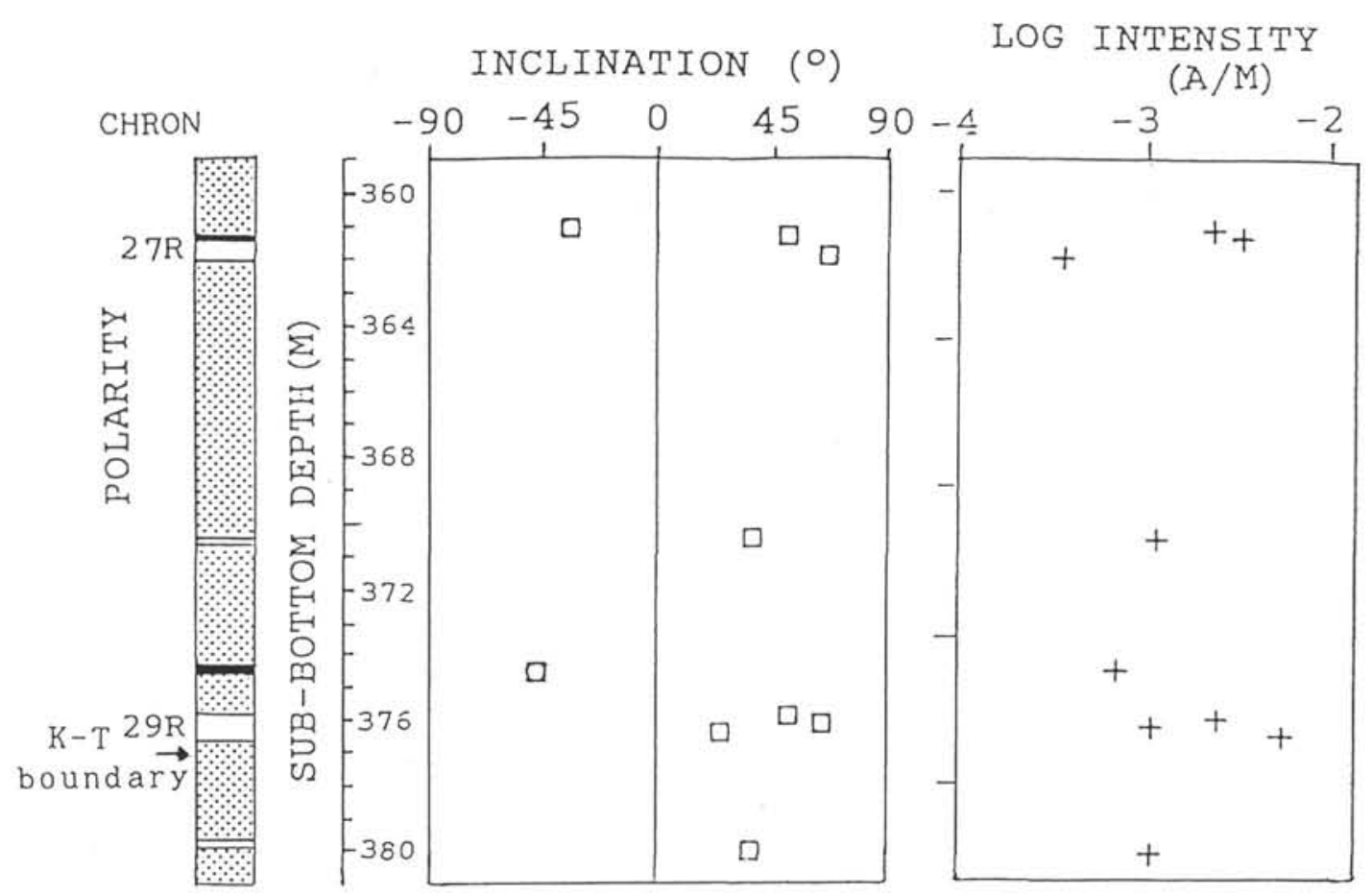

Figure 13. Magnetic inclination and polarity interpretation of the Cores $119-738 \mathrm{C}-19 \mathrm{R}$ to $119-738 \mathrm{C}-20 \mathrm{R}$ vs. depth. K/T shows the Cretaceous/Tertiary boundary. 


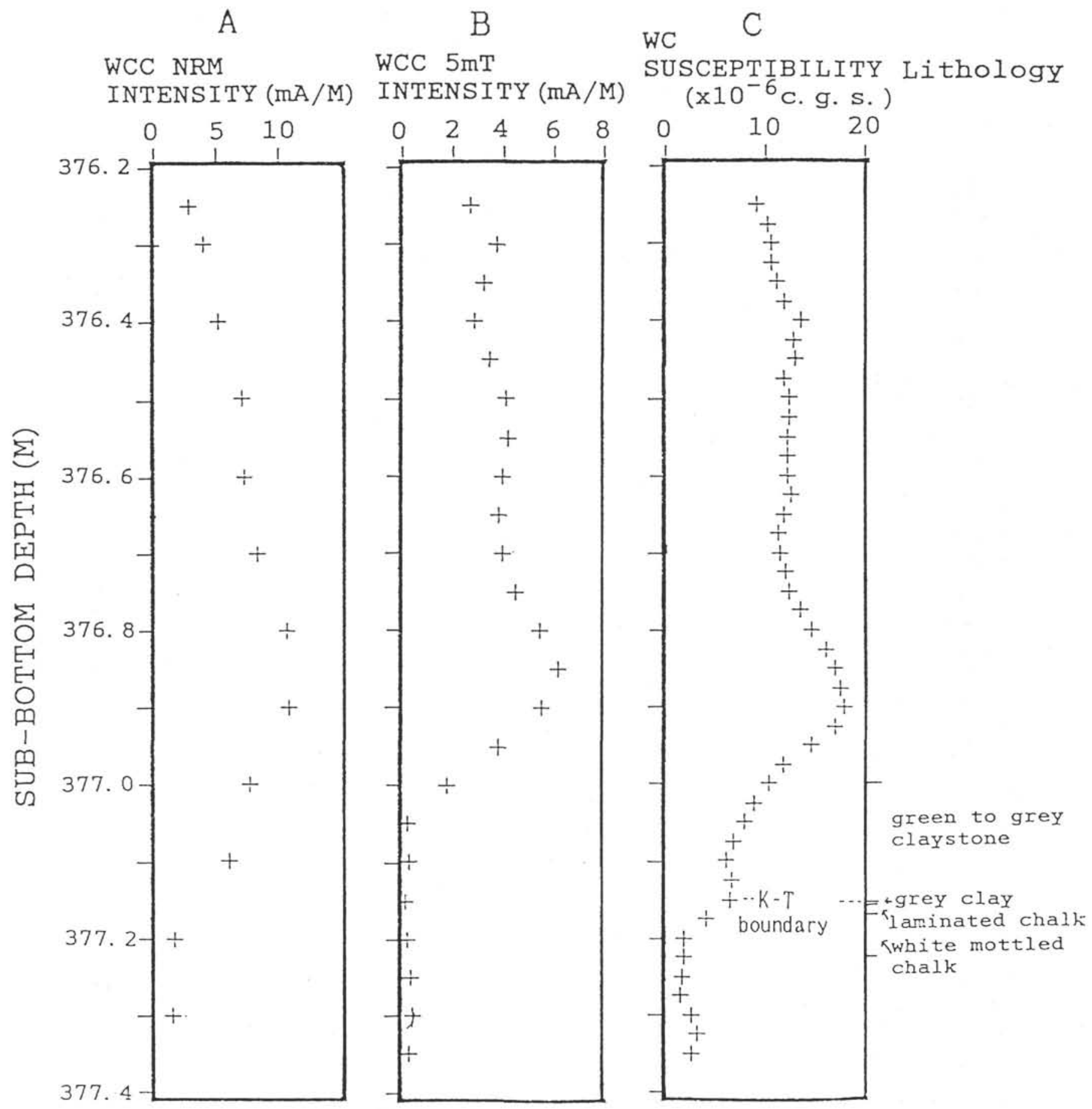

Figure 14. Downhole variation of magnetization intensity and susceptibility measured on the archive half of Section 119-738C-20R-5. The lithology at the Cretaceous/Tertiary boundary is to the right. K/T shows the Cretaceous/Tertiary boundary. A. NRM intensity measured at a 10-cm interval by the whole-core cryogenic magnetometer. B. Intensity after $5 \mathrm{mT} \mathrm{AF}$ demagnetization. Measurement was made at a 5-cm spacing. C. Susceptibility measured at a $2.5-\mathrm{cm}$ spacing by the whole-core susceptibility meter. 


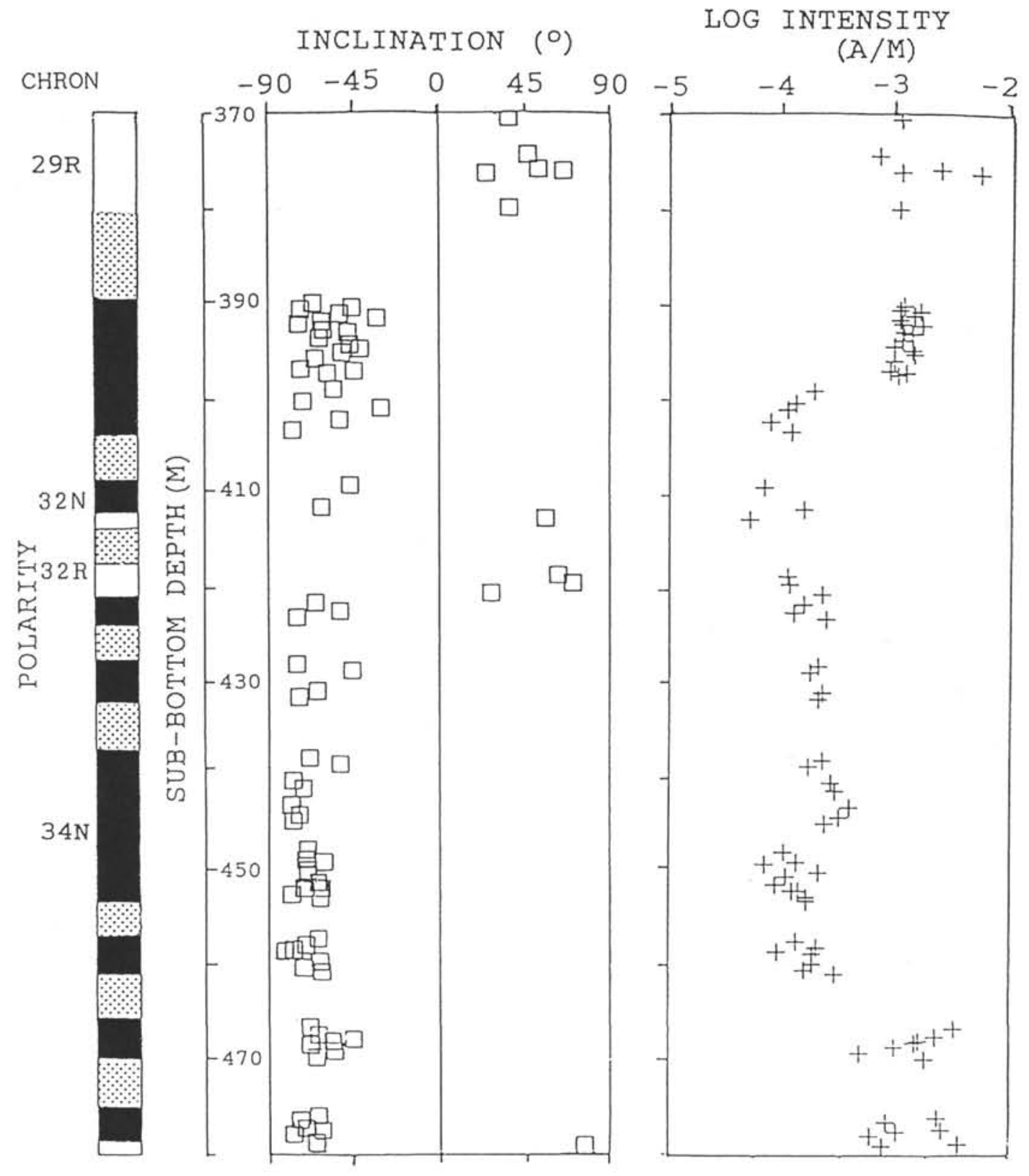

Figure 15. Magnetic inclination, NRM intensity, and polarity interpretation of Cores 119-738C-20R to $119-738 \mathrm{C}-25 \mathrm{R}$ vs. depth. Black and white indicate normal and reversed polarity, respectively; the dotted pattern indicates gaps in the record. 


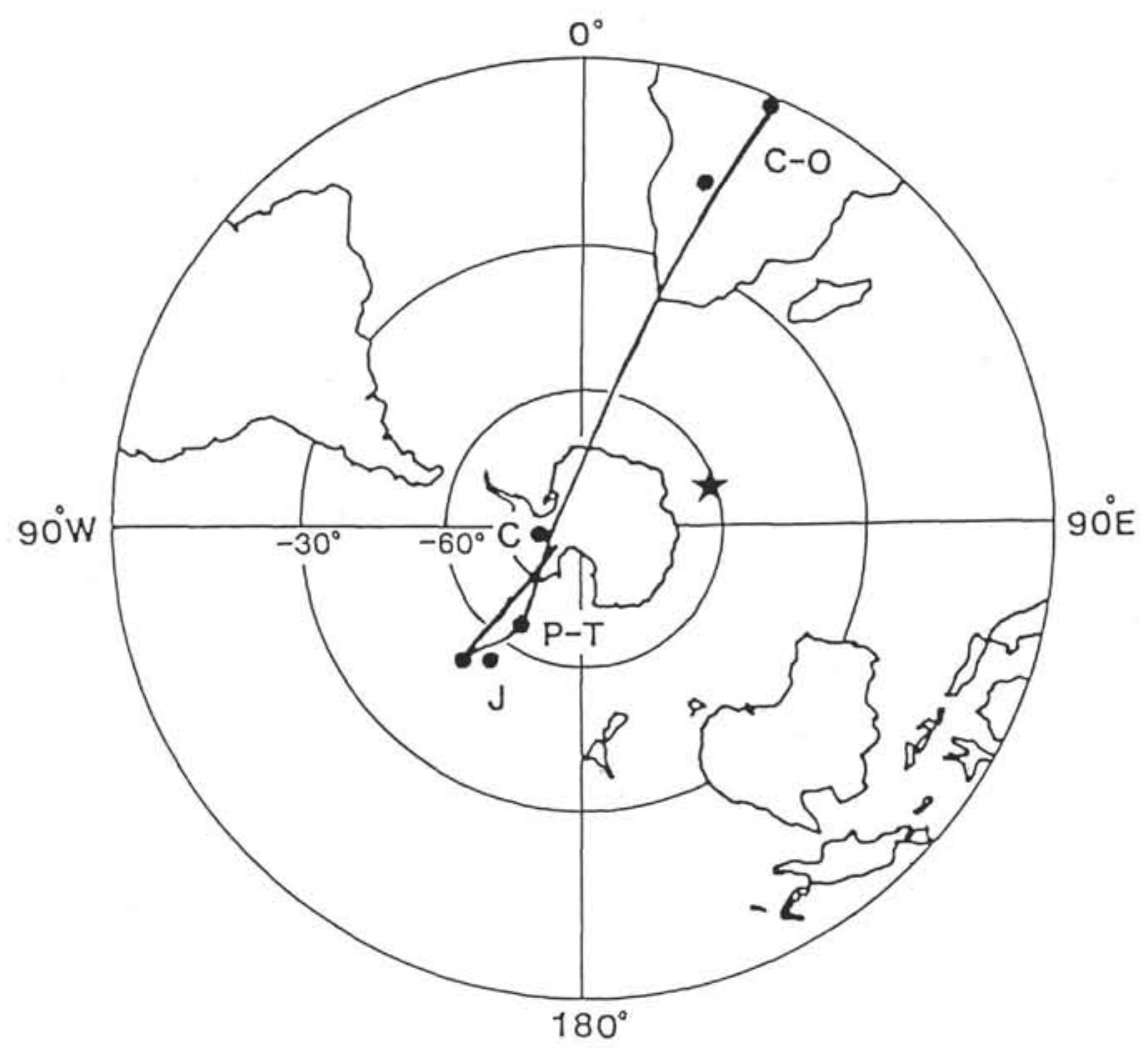

Figure 16. Apparent polar-wander paths for Antarctica compiled by Funaki (1984). Paleopole positions are represented as follows. $\mathrm{C}-\mathrm{O}=$ Cambro-Ordovician, $\mathrm{P}-\mathrm{T}=$ Permo-Triassic, $\mathbf{J}=$ Jurassic, C = Cenozoic (Tertiary). Star mark shows the position of Hole 738C. 


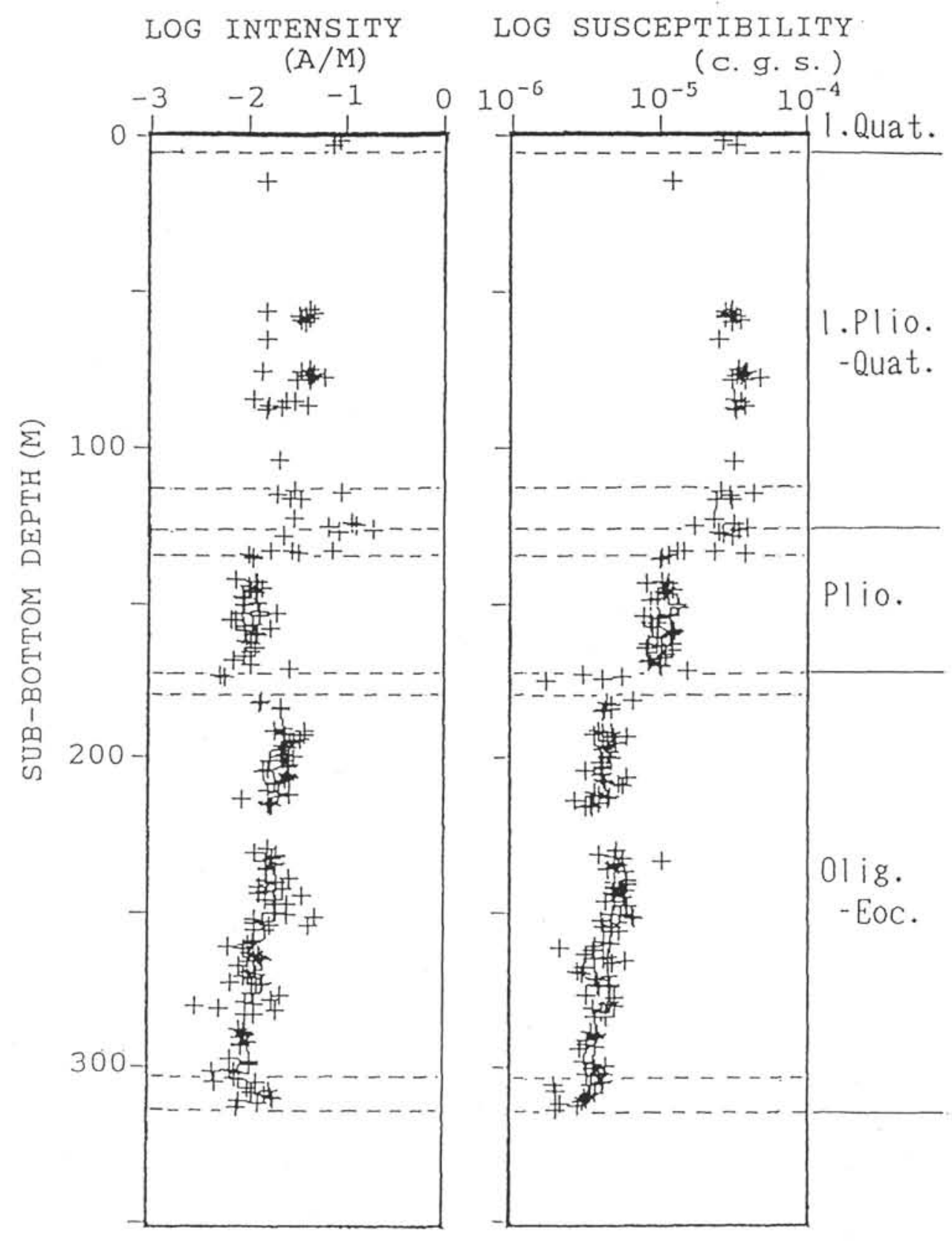

Figure 17. Downhole variation of NRM intensity and magnetic susceptibility of Holes 742A. Dotted lines represent the lithological boundary. The estimated age from biology is shown in right. Quat.= Quaternary; Plio. = Pliocene; Olig. $=$ Oligocene; Eoc. = Eocene; $1 .=$ lower. 

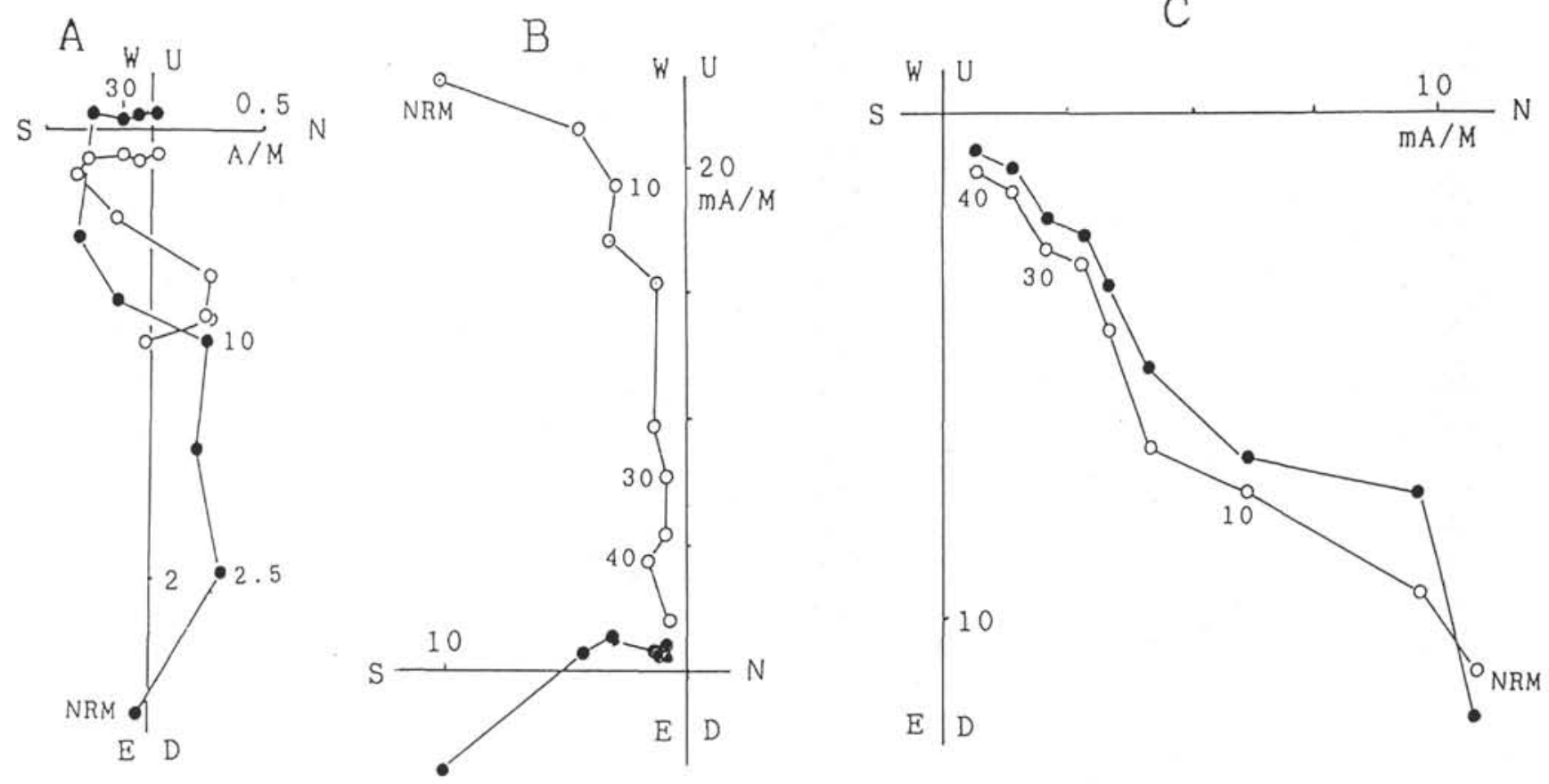

Figure 18. Representative orthogonal vector plots of demagnetization curves of samples from Hole 742A. A. Sample 119-742A-15R-4, 106 cm; AF demagnetization. B. Sample 119-742A-22R-1, $23 \mathrm{~cm}$; AF demagnetization. C. Sample 119-742A-24R-1, $114 \mathrm{~cm}$; AF demagnetization. Conventions as Figure 2. 


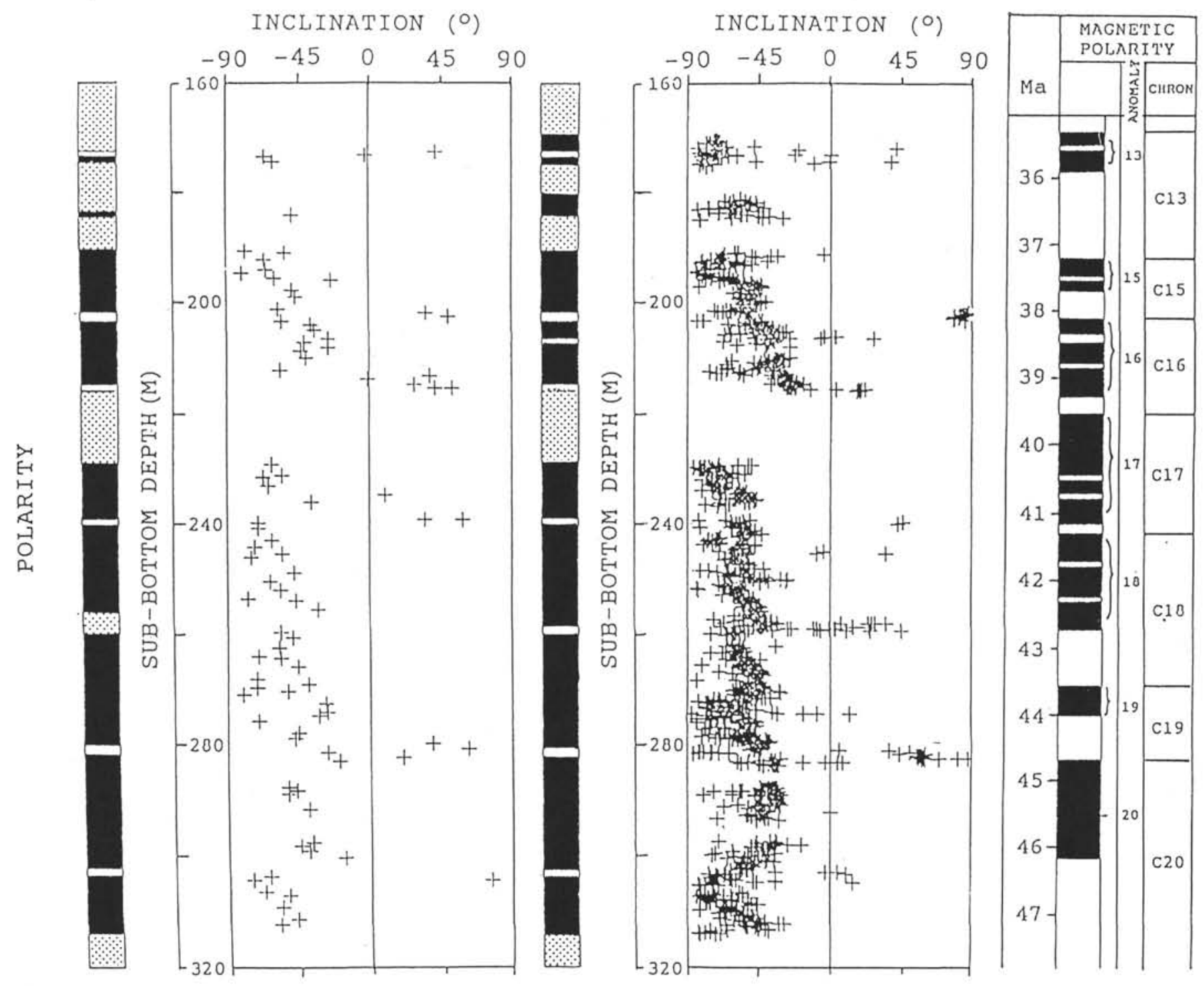

Figure 19. Plot of magnetic inclination from discrete samples and from whole core measurements on the Hole $742 \mathrm{C}$ vs. depth. Interpreted magnetic polarity is shown in the box on left. In the right, time scale between Chron C20 and Chron C13 by Berggren et al. (1985) is shown. 